\title{
KONVICE S TŘMENOVÝM UCHEM A ZOOMORFNÍMI VÝLEVKAMI V BRNĚNSKÉM PROSTŘEDÍ
}

\author{
LENKA SEDLÁČKOVÁ - PAVEL STANĚK - MARTIN HLOŽEK
}

\begin{abstract}
Abstrakt: Konvice s třmenovým uchem obecně patři na jižní Moravě $k$ raným projevi̊m kulturních vlivi̊ z rakouského Podunaji, které jsme schopni v tehdejši keramické produkci rozpoznat. V brněnských nálezech se tento specifický keramický tvar objevuje od 13. století ve třech základních formách-jako „klasické“ tvary třmenových konvic, miniaturní nádobky a konečně jako stolní konvice se dvěma zoomorfně ztvárněnými výlevkami. Zvláště nálezům posledně zmíněného typu bude věnována pozornost, včetně mikropetrografických rozborů vybraných exemplár̆u.
\end{abstract}

Klíčová slova: konvices třmenovým uchem - konvice s třmenovým uchem a zoomorfními výlevkami - glazovaná keramika - petroarcheologie keramiky - Brno.

\section{Ewers with stirrup handles and zoomorphic spouts in the Brno milieu}

Abstract: Ewers with stirrup handles in South Moravia count among the early manifestations of cultural influences from the Austrian Danubian Basin that can be identified in the pottery production of the period. In Brno, this specific shape first appeared in the 13th century, in three basic forms: "classic" stirrup ewers, miniature vessels and table ewers with two zoomorphically shaped spouts. This study focuses, in particular, on the finds of the last mentioned type, including micropetrographic analyses of selected specimens.

Key words: ewers with stirrup handles - ewers with stirrup handles and zoomorphic spouts - glazed pottery-petroarchaeology of ceramic-Brno.

\section{Úvod}

Konvice $\mathrm{s}$ třmenovým uchem ${ }^{1}$ jsou $\mathrm{v}$ Brně novým keramickým tvarem, který je dobře spojitelný $\mathrm{s}$ nově př́íchozím obyvatelstvem během 13. století z oblastí ležících jižně a jihozápadně Moravy. Za domovinu třmenových konvic je již tradičně považována oblast jihozápadního Německa, kde se tyto tvary objevují snad již od první poloviny 12. století, přičemž plného rozmachu doznaly zvláště ve druhé polovině tohoto věku. Jejich vývoj je obecně předpokládán z tvarů konvic se dvěma uchy (tzv. Doppelhenkelkanne), které posléze, snad již během druhé poloviny 12. století, třmenové konvice pomalu nahrazují (Gross 1991, 69-77; 1991a, 101-105; Scharrer-Liška 2007, 58).

V oblastech rakouského Podunají se třmenové konvice objevují během druhé poloviny 12. století, zvláště pak ve století následujícím (Huber-Küthreiber-Scharrer 2003, 52; Scharrer-Liška 2007, 58-60). Dunajskou cestou se šiří dále východním směrem a snad již na přelomu 12. a 13. století jsou známé z Bratislavy (Hoššo 1997, 288, tab. I:12, 14; Hoššo-Lesák 2001, 245, 249, obr. 3:3) a během první poloviny 13. století se s nimi setkáváme i na jižní Moravě (Procházka-Peška 2007, 223; Unger 1984, 293). Prozatím je však výrazněji postrádáme z Mad’arska (srov. Holl 1963, 335-394; Takács 1996, 135-195). Již z první poloviny 13. století jsou konvice s třmenovým uchem uváděny z přilehlé části Saska (Kenzler 2001, 91; Beutmann 2012, 177, 180, 182) a kolem poloviny 13. století se objevují i v Čechách (Richter 1982, 126).

\section{Třmenové konvice v brněnském prostředí}

$\mathrm{S}$ třmenovými konvicemi se v brněnském prostředí setkáváme ve třech různých formách.

Nejstarším typem jsou ,klasické“ konvice kulovitých tvarů vysoké kolem $25 \mathrm{~cm}$, které bývají vyrobeny z keramického těsta vypáleného do světle šedých až okrových odstínů, mnohdy

1 Typologicky se jedná o konvice, které jsou opatřeny třmenovým uchem, které vychází i nasedá na okraj nádoby. Na rozdíl od konvic se dvěma výlevkami, kde je ucho místěno v ose výlevek, je u „klasických“ konvic ucho umístěno vždy kolmo k trubkovité výlevce. Terminologicky správně by měl být použiván název „konvice s trubkovitou výlevkou a třmenovým uchem“. Ryze z praktických důvodů je v textu použíán zjednodušený pojem „třmenová konvice“. 
s př́měsí slídy, ojediněle se objeví i konvice v tuhovém provedení. ${ }^{2}$ Jejich těla nebývají zdobena, někdy na plecích nalezneme nevýraznou šroubovici či žlábkování. Výzdobou však bývá většinově opatřeno masivní ucho oválného průřezu - šikmými vrypy, vpichy, záseky či nějakým typem radélka či kolku (obr. 1).

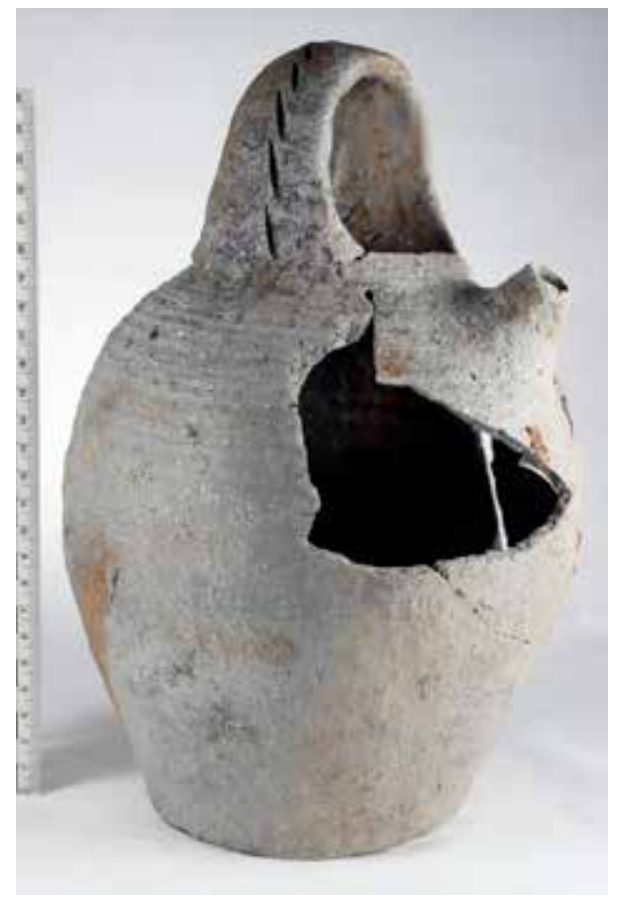

Obr. 1. Typický tvar i provedení třmenových konvic v Brně. Výzkum před výstavbou Janáčkova kulturního centra v Brně (A006/2015), 13. století. Foto Archaia Brno.

Abb. 1. Typische Form und Ausführung der Bügelkannen in Brünn. Grabung vor dem Bau des Janáček-Kulturzentrums in Brno (A006/2015), 13. Jhdt. Foto Archaia Brno.

Nejstarší nálezy jsou v Brně známé již před polovinou 13. století (horizont VS 1.2; Procházka-Peška 2007, 223; Přibylová 2013, 68-71), výrazněji jsou zastoupeny v souborech druhé poloviny 13 . století až počátku 14. století. V tomto období se s nimi také setkáváme téměř na všech lokalitách zasažených kulturními vlivy z podunajské oblasti, byt' mnohdy s jistým časovým odstupem v závislosti na postupující kolonizaci daných oblastí, či prosazující se keramikou nových kvalit.

Jejich výskyt je, až na prozatím ojedinělé nálezy ze střední a severní Moravy (např. Procházka-Kováčik-Zůbek 2002, 207, obr. 11:8, 208; Kouřil-Wihoda 2003, 92-94, obr. 10:1; Kováčik-Dudková-Lafková 2016, 185, obr. 13), omezen na prostor Moravy jižní a jihovýchodní. Tato situace však může být ovlivněna nerovnoměrným stavem zpracování nálezů keramiky na Moravě. Výrazné zastoupení pak mají třmenové konvice i v prostoru jihozápadní Moravy. Několik exempláŕů pochází z hornické aglomerace Staré Hory u Jihlavy, stejně jako ze samotného města, kde se prvně objevují ve druhé třetině 13 . století (Hrubý a kol. 2006, 210; Zimola 2014, 208, 212, 217).

Snad již kolem poloviny 13. století se třmenové konvice objevují i v Čechách, kde je jejich př́tomnost taktéž dobře spojitelná s kulturními vlivy z oblastí ležících západně a jihozápadně Čech. Většinou, byt' nikoliv výlučně se jedná o keramiku světlého střepu, mnohdy červeně malovanou. Tradice výroby této specifické hrnčiny jsou hledány také v oblastech jižního Německa, přičemž na našem území se jedná o import znalosti technologie výroby, nikoliv import výrobků samotných, jak dokládají četná výrobní centra této keramiky fungující od druhé poloviny 13. století zvláště v oblasti severních a severozápadních Čech, ale také v Praze a jejím okolí (Nekuda-Reichertová 1968, 137 150; Richter 1982, 126-129, 134, 136; Gabriel-Smetana 1983, 119-138; Klápště 1998, 138-158; Hentsch 2010, 27-28, obr. 46:4, snad i 5; Havrda-Matějková 2014, 23-51). Touto módní vlnou byla ve druhé polovině 13. století částečně zasažena i oblast východních Čech (srov. Hradec Králové - Richter-Vokolek 1995, 69, tab. 117; Čáslav - Frolík a kol. 1999, 40, kat. č. 166; další nálezy Klápště 1998, obr. 4b). Poněkud překvapivě se s třmenovými konvicemi prozatím (?) setkáváme pouze ojediněle v jižních a západních Čechách, což může být způsobeno tím, že vlivy z prostředí rakouského a bavorského se na místní keramice výrazněji uplatňují až od 14. století (Vařeka 1998, 134; Čapek-Militký a kol. 2016, 370-371), kdy jsou konvice již na ústupu.

2 Prozatím ojedinělým nálezem je zlomek snad třmenového ucha a těla konvice s výlevkou z výzkumu před výstavbou Janáčkova kulturního centra v Brně (akce A006/2015, s. j. 18394/64 a 75). Soubor je na základě ostatní keramiky předběžně datován do období 2. poloviny 13. století. Také v rakouském prostředí se ojediněle tuhové exempláře objeví (Scharrer-Liška 2007, 60). 
Předpokládá se, že třmenové konvice pravděpodobně ještě ve 13. století náhle mizí z tvarového spektra a jsou nahrazeny džbány, přičemž o něco déle je tento tvar užíván v Čechách než na Moravě (Klápště 1998, 143-144, 147-150; Procházka-Peška 2007, 229). V brněnském prostředí se s nimi setkáváme ještě v souborech z odpadních jímek 14. století, jsou však většinově považovány za nálezy reziduální. Ve většině př́ípadů je téměř nemožné odlišit nálezy terciárního charakteru od přežívající výrobní tradice tohoto tvaru. Je ovšem pravdou, že právě od 14. století můžeme v brněnských souborech pozorovat výrazný nástup džbánů, které pravděpodobně převzaly funkci třmenových konvic, a lépe tak obstály v konkurenčním boji funkčně podobných tvarů.

$\mathrm{V}$ některých regionech Bavorska a Horního Rakouska přežívají tyto tvary ještě $\mathrm{v}$ závěru 14. a v 15. století, jak naznačují nálezy z Řezna (Endres 1998, 277-284; Procházka-Peška 2007, 223) či nálezy konvic v rámci výrobního odpadu z Enže (Kaltenberger 2009, 470-471, kat. č. EN-B 39 až EN-B 41; Kaltenberger 2009a, 160-161, Taf. 34). Běžnou součástí tvarového spektra 13. až 15. století jsou také v oblastech severního Švýcarska, někdy i v glazovaném provedení (Keller 1999, 73-75; Pfrommer-Gutscher 1999, 147-148).

Přestože $v$ Brně je jejich výskyt omezen maximálně na jeden až dva exempláře $v$ rámci jedné parcely, byly třmenové konvice pravděpodobně nedílnou součástí většiny tehdejších domácností. Jejich větší počet nebo i celé tvary pochází pouze ze zásypů studní, což dobře koresponduje $\mathrm{s}$ jejich předpokládanou funkcí k čerpání (?), ${ }^{3}$ zvláště však $\mathrm{k}$ přenášení a uchovávání vody či jiných tekutin. Některé, zvláště snad menší exempláře mohly sloužit na jídelní tabuli $\mathrm{k}$ rozlévání tekutin ve funkci džbánu, vyloučit nemůžeme ani jejich užití k omývání rukou - jako aquamanile.

Jejich výskyt není omezen na určité sociální prostředí, nebot' tyto tvary jsou známé jak z měst a městeček ${ }^{4}$ či šlechtických sídel, ${ }^{5}$ tak i z vesnického prostř̌edí, ${ }^{6}$ byt' masového rozšiřrení tento tvar nikdy nedoznal, či spíše nestihl doznat.

Snad již během druhé poloviny 13. století, výrazněji však v první polovině 14 . století, se třmenové konvice $\mathrm{v}$ brněnském prostředí objevují v rámci miniaturních nádobek, a to jak v glazovaném, tak režném provedení (obr. 2 a 3). Výskyt miniaturních nádobek rozličných tvarů i materiálů je dokumentován z rozsáhlého území střední, západní i severní Evropy od pokročilého 12. století, zvláště pak ve století následujícím (např. Lobbedey 1968, 40-42; Felgenhauer-Schmiedt 1982, 112-116; Lüdtke 1985, 54-59; Gross 1991a, 83; Madsen 1991, 427-440; Hoffmann 1997, 40; Beutmann-Kenzler 2004, 485-494; Auch-Trzecieczki 2007, 146-147). $\mathrm{V}$ brněnském prostředí jsou miniaturní nádobky obecně předpokládány již v rámci horizontu druhé třetiny 13. století (Procházka-Peška 2007, 229), přičemž k jejich většímu uplatnění došlo zvláště ve 14. století, ojediněle se objevují i v souborech z přelomu 14. a 15. století (Procházka 1996, 331). Obdobnou situaci můžeme předpokládat pro celou oblast Moravy (srov. Unger 1984, 292-294; Procházka-Hložek 2013, 238-242; Sedláčková 2015, 208-209) a výjimkou asi nebudou ani Čechy (srov. Richter 1961, 573-579).

Novější nález depotu mincí z Prštic (okr. Brno-venkov) byl uložen právě v miniaturní třmenové konvičce, a potvrzuje tak výskyt tohoto tvaru již v závěru 13. století (Grossmannová-Navrátil 2016, 105-118).

Na rozdíl od miniaturních nádobek v podobě štíhlých hrnců, jejichž funkční upotřebení, pomineme-li dětské hračky, je shledáváno v uložení ceněného koření a mastí, musely být miniatury třmenových konvic používány k rozlévání tekutin. $\mathrm{V}$ úvahu připadá např́íklad přechovávání tekutých přisad na jídelním stole, snad mohly tyto tvary sloužit i jako lahvičky pro kojence či starce. Zcela vyloučit nemůžeme ani jejich užití k omývání rukou ve funkci aquamanile.

\footnotetext{
3 Keramické tvary se ze své křehké podstaty přímo k čerpání nehodí. Jejich početné nálezy právě z objektů interpretovaných jako studny však toto funkční upotřebení podporují. Z publikovaných souborů uved'me např. studnu z Brna, Františkánské ulice (Procházka-Peška 2007, 219), Hradišt'ko u Davle (Richter 1982, 52-53, 76, 86, obr. 56, 66-68) a Leobendorf v Dolním Rakousku (Krenn 2011, 95-97, 103, tab. 70, 71). 4 Vedle Brna je to např. Uherské Hradiště (Otakarova ulice, 2. polovina 13. století; Procházka 1984, 438), Lednice (Dejmal-Zbranek 2013), Třebíč (Poláček 1992,111-113, 119-123, obr. 66:35 a 70:40), Doubravník (horizont A ze 13. století; Staněk 2014, 104), Staré město ve Žd’áru nad Sázavou (Zatloukal 1999, 198).

5 Např. hrad ve Veselí nad Moravou (Sedláčková 2015, 202), Smilovo Hradisko na Prostějovsku (Blekta 1934, 16, tab. IV:49).

6 Např. Bystřec (Belcredi 2006, 328), Konůvky (Měchurová 1997, 60), Šakvice (Unger 1981, 74), Koválov (Měřínský-Unger 1987, 9 , tab. 36:5 a 6), Studýň u Zbýšova (Měŕnský 1977, 67), Černá Hora (Procházka-Štrof 1983, 54, obr. 5:10), Topolany (Unger 1984a, 79, obr. 9:5).
} 


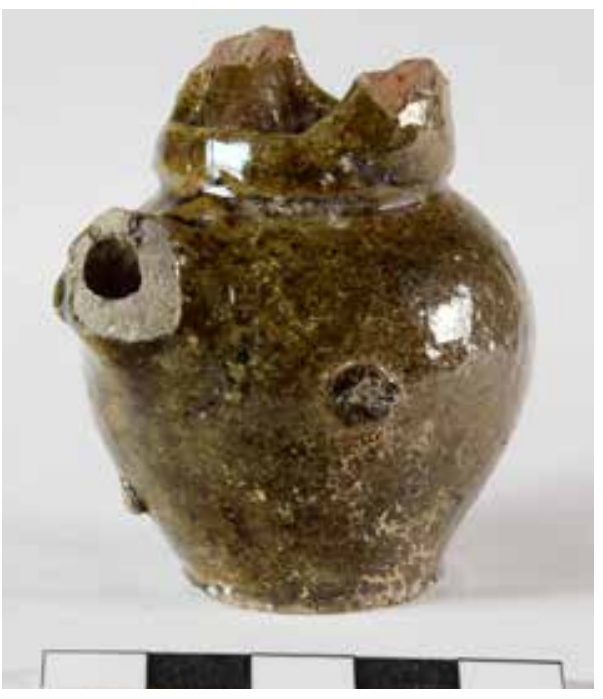

Obr. 2. Glazovaná miniatura třmenové konvice. Výzkum před výstavbou Janáčkova kulturního centra v Brně (A006/2015), první polovina 14. století. Foto Archaia Brno. Abb. 2. Glasierte Bügelkännchen. Grabung vor dem Bau des Janáček-Kulturzentrums in Brno (A006/2015), 1. Hälfte 14. Jhdt. Foto Archaia Brno.

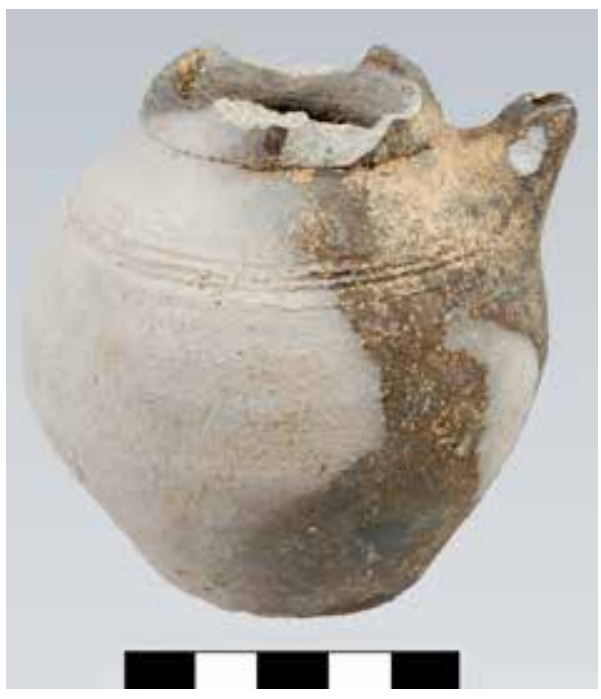

Obr. 3. Miniatura třmenové konvice. Výzkum při výstavbě Obchodní galerie Velký Špalíček (A10/2000), 13./14. století. Foto Archaia Brno.

Abb. 3. Bügelkännchen. Grabung beim Bau der Geschäftsgalerie Velký Špalíček (A10/2000), 13./14. Jhdt. Foto Archaia Brno.

Nepočetný, i když běžný výskyt miniaturních nádobek v celém evropském prostoru je důvodem, že jsou většinou považovány za importované zboží (Beutmann-Kenzler 2004, 492; Procházka-Hložek 2013, 240). Vzhledem k širokému tvarovému i materiálovému spektru, různým způsobům výzdoby a relativně dlouhému časovému horizontu jejich výskytu je nutné uvažovat o více výrobních centrech (srov. např. Šikulová 1985, 230-232; Janssen 1987, 27; Hoffmann 1997, 40; Beutmann-Kenzler 2004, 492-493; Havrda-Matějková 2014, 30, 39).

Pro Brno předpokládáme, že část těchto výrobků, zvláště keramika jemného bílého stř̌epu, se na místní trhy dostávala ze vzdálenějších oblastí, bud' jako méně běžné či hůřre dostupné zboží, často snad také jako obal ceněného zboží. Prozatím nebyly u tohoto druhu nálezů provedeny petrografické analýzy, tudíž je otázkou, zda by bylo možné u některých miniaturních nádobek uvažovat o místní produkci.

Vyvrcholením tohoto tvaru jsou třmenové konvice se dvěma výlevkami v podobě zvírecích hlaviček. Brněnské exempláře jsou, až na jednu výjimku, vždy opatřeny glazurou.

Mezi brněnskými nálezy bylo prozatím rozpoznáno deset exemplářu tohoto typu třmenových konvic (kat. č. $1-8,11,12^{7}$ ). Další dva nálezy by snad mohly z tohoto tvaru pocházet (kat. č. 9 a 10 ; obr. $4-6)$.

Téměř cele dochovaný exemplář a dva větší kusy (kat. č. 1, 2 a 5) dovolují soudit, že se jedná o menší tvary s výškou kolem $15 \mathrm{~cm}$, s třmenovým uchem pak dosahují výšky kolem $20 \mathrm{~cm}$. Ucho oválného až kruhového průřezu bývá výrazně obloukovitě klenuto, vždy v ose výlevek, což bezpochyby výrazně usnadňovalo rozlévání tekutiny za pomoci pouze jedné ruky. Konvice postrádají jakoukoliv výzdobu; pouze třmenové ucho konvice z Panenské ulice (kat. č. 1) bylo opatřeno drobným vtlačeným kroužkem a ucho neglazované konvice z téže lokality (kat. č. 11) neuspořádanými záseky. V obecném pohledu se jedná o baňatější tvary, nad jejichž maximální

7 Exemplář kat. č. 12 nebyl bohužel dohledán, a proto není v obecných charakteristikách tohoto tvaru zohledněn. 


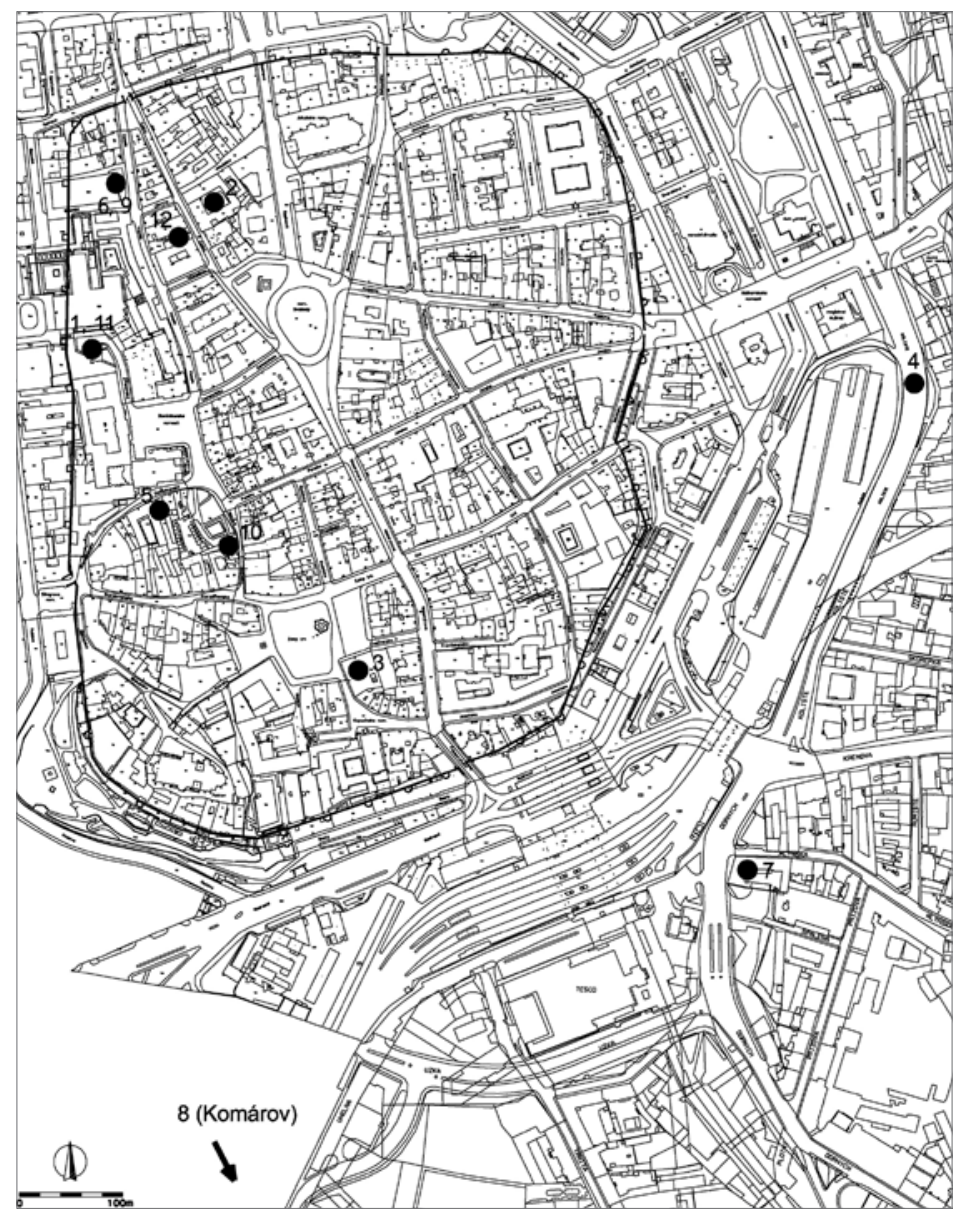

Obr. 4. Mapa Brna s vyznačením nálezů třmenových konvic se zoomorfními výlevkami. 1, 11 - Panenská ulice (A014/2009); 2 - Česká 6 (A094/2012); 3 - Květinářská ul. - Reduta (A030/2002); 4 - Koliště (A064/2004); 5 - Dominikánská 7 (A010/2000); 6, 9 - Veselá ulice - Janáčkovo kulturní centrum (A006/2015); 7 - Mlýnská ul. - Metropol (výzkum MZM v roce 1997); 8 - Komárov - benediktinský klášter (výzkum MMB v roce 1976); 10 - Mečová 4 (A010/2000); 12 - Česká 5 (výzkum AÚ 1985).

Abb. 4. Karte von Brno mit eingezeichneten Funden von Bügelkannen mit zoomorphen Ausgüssen. 1, 11 - Panenská-Str. (A014/2009); 2 - Česká-Str. 6 (A094/2012); 3 - Květinářská-Str. Reduta (A030/2002); 4 - Koliště-Str. (A064/2004); 5 - Dominikánská-Str. 7 (A010/2000); 6, 9 - Veselá-Str. - Janáček-Kulturzentrum (A006/2015); 7 - Mlýnská-Str. - Metropol (Grabung des Mährischen Landesmuseums im Jahr 1997); 8 - Stadtteil Komárov - Benediktinerkloster (Grabung des Museums der Stadt Brünn im Jahr 1976); 10 - Mečová-Str. 4 (A010/2000); 12 Česká-Str. 5 (Grabung des Archäologischen Instituts 1985).

výdutí jsou umístěny výlevky. Okrajová profilace, žel dochovaná jen ve dvou případech, sestává z okraje římsovitého (kat. č. 1) a střechovitě seříznutého (kat. č. 2). Neglazovaná konvice z Panenské ulice (kat. č. 11) má okraj přímý. Materiálově si jsou studované nálezy velmi podobné. Keramická hmota je vypálena v odstínech cihlové barvy, někdy je místy zbarvená do světle šedé barvy. Svým materiálem, ale i velmi tvrdým výpalem se mírně odlišuje výlevka z Veselé ulice (kat. č. 6), jejíž střep je na lomu šedý a v porovnání s ostatními exempláři i relativně tenkostěnný. Materiálově se však nejen $\mathrm{z}$ tohoto druhu nálezů v brněnském prostředí vymyká třmenová 


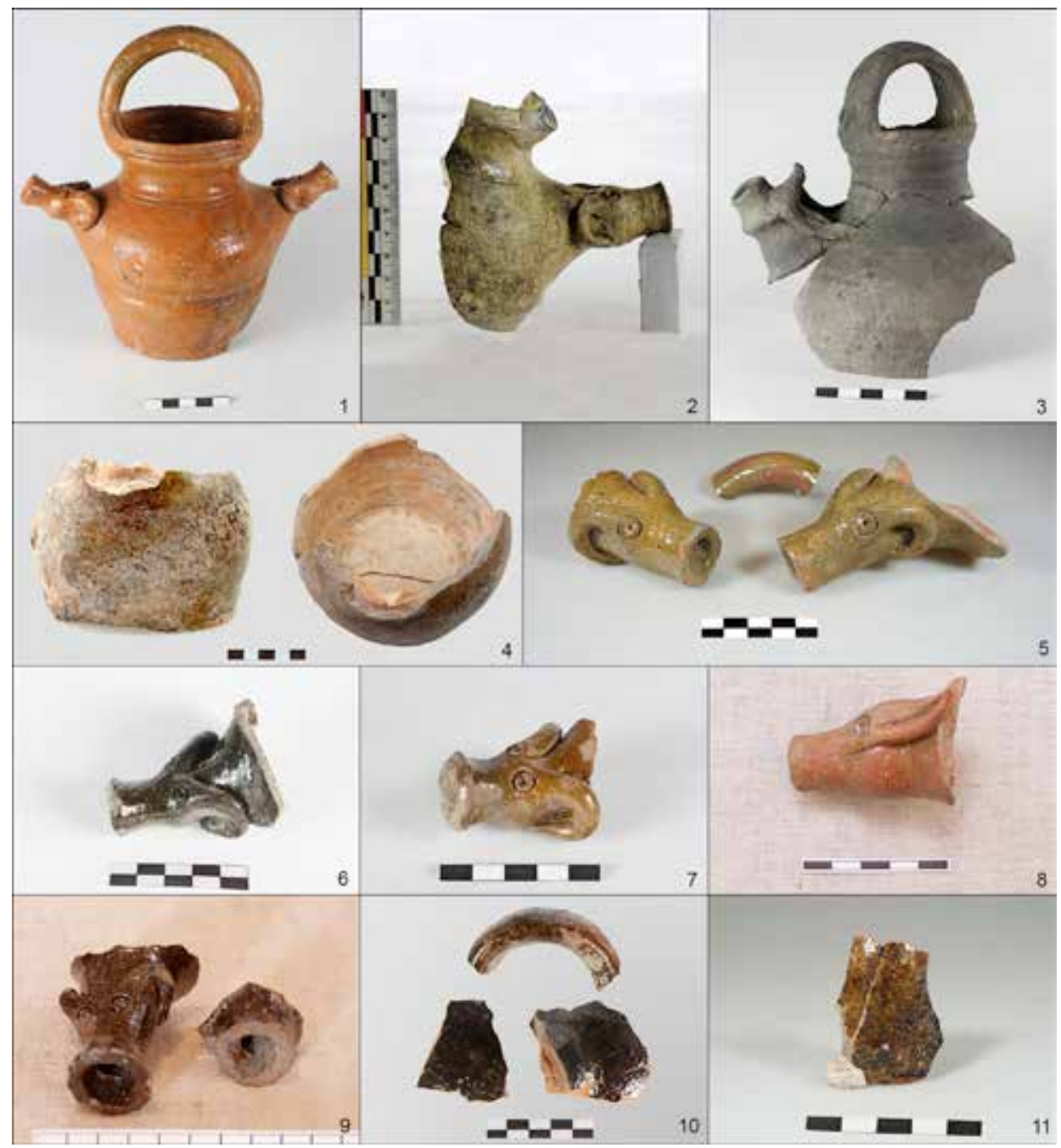

Obr. 5. Brněnské nálezy třmenových konvic se zoomorfními výlevkami. 1 - Panenská ulice (kat. č. 1); 2 - Česká 6 (kat. č. 2); 3 - Panenská ulice (kat. č. 11); 4 - Dominikánská 7 (kat. č. 5); 5 - Květinářská ul. (kat. č. 3); 6 - Veselá ulice - Janáčkovo kulturní centrum (kat. č. 6); 7 - Mlýnská ul. (kat. č. 7); 8 - Komárov (kat. č. 8); 9 - Koliště (kat. č. 4); 10 - Veselá ulice Janáčkovo kulturní centrum (kat. č. 9); 11 - Mečová 4 (kat. č. 10). Foto Archaia Brno.

Abb. 5. Brünner Funde von Bügelkannen mit zoomorphen Ausgüssen. 1 - Panenská-Str. (Kat. Nr. 1); 2 - Česká-Str. 6 (Kat. Nr. 2); 3 - Panenská-Str. (Kat. Nr. 11); 4 - Dominikánská-Str. 7 (Kat. Nr. 5); 5 - Květinářská-Str. (Kat. Nr. 3); 6 - Veselá-Str. - Janáček Kulturzentrum (Kat. Nr. 6); 7 - Mlýnská-Str. (Kat. Nr. 7); 8 - Stadtteil Komárov (Kat. Nr. 8); 9 - Koliště-Str. (Kat. Nr. 4); 10 - Veselá-Str. - Janáček Kulturzentrum (Kat. Nr. 9); 11 - Mečová-Str. 4 (Kat. Nr. 10). Foto Archaia Brno.

konvice z České 6 (kat. č. 2), jejíž střep je vypálen do bělavé barvy. Ze zcela odlišné keramické hmoty je vyrobena i nepolévaná konvice z Panenské ulice (kat. č. 11). Její keramické těsto je relativně hrubé, ostřené drobnými kamínky a vypálené do světle růžového odstínu, povrch střepu je světle šedý.

Vnější povrch třmenových konvic bývá opatřen polevou, přičemž její kapky bývají mnohdy četně zatečeny $\mathrm{i}$ do vnitřku nádoby. Barva glazury je $\mathrm{v}$ rámci jednotlivých exemplář značně 

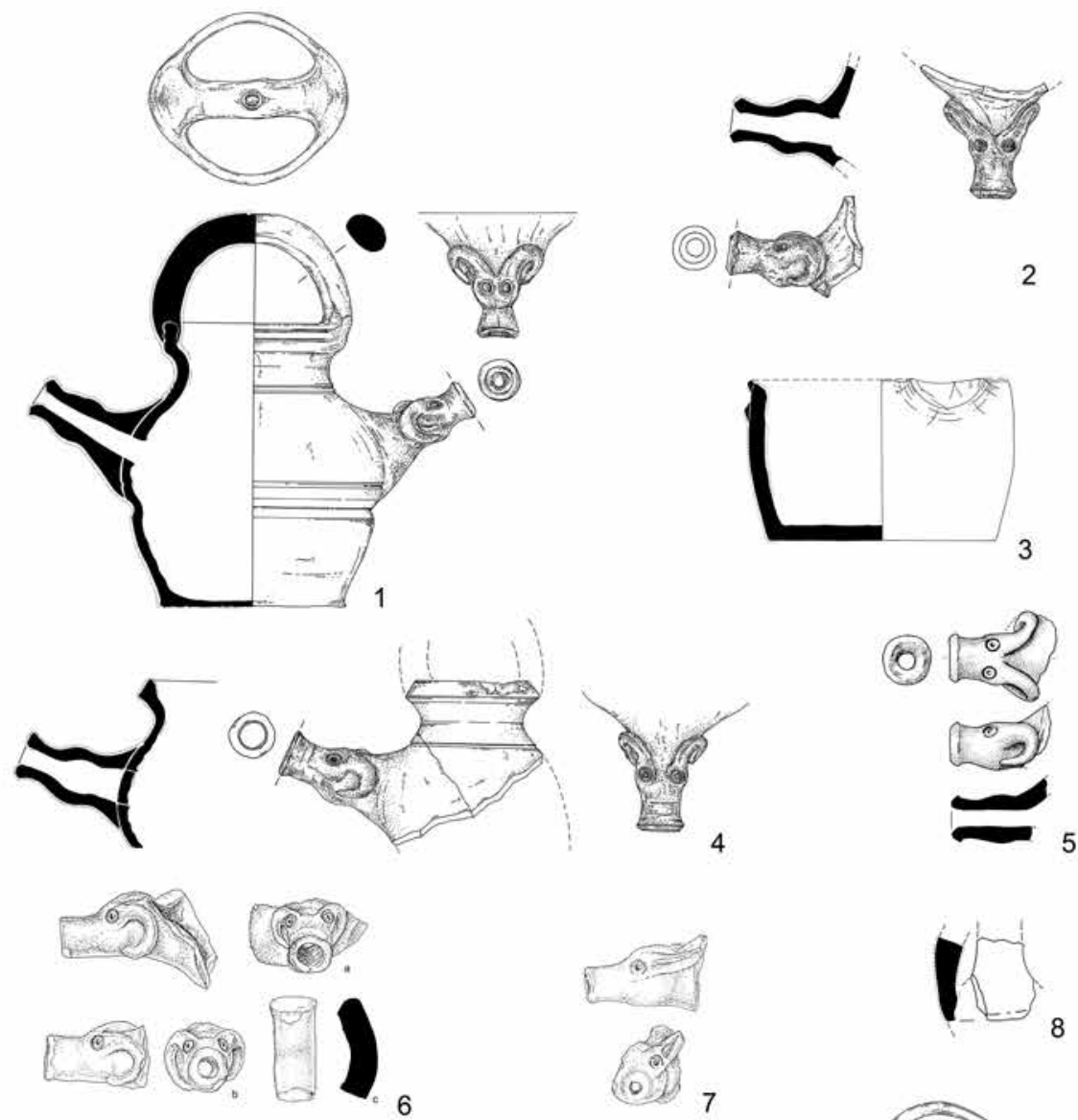

7
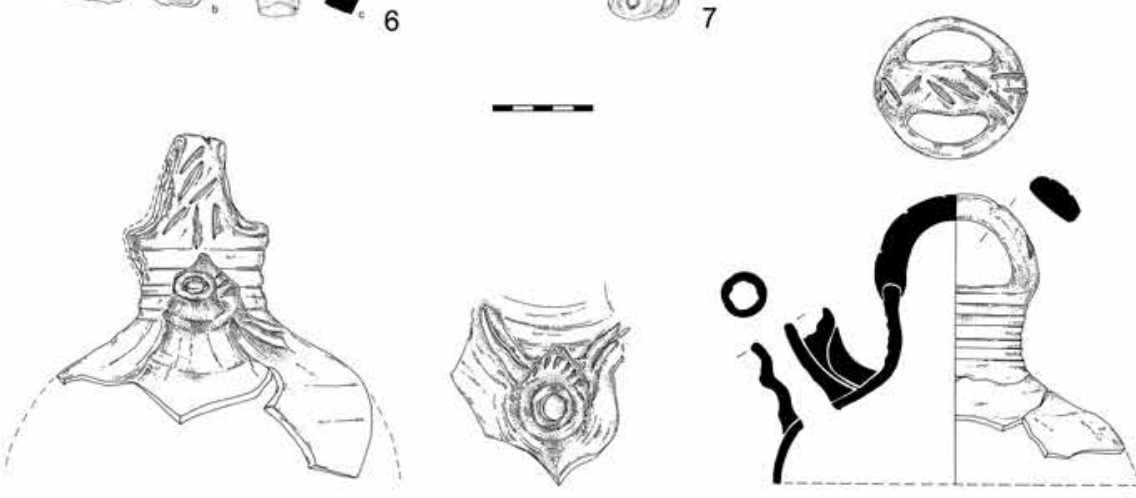

Obr. 6. Brněnské nálezy třmenových konvic se zoomorfními výlevkami. 1 - Panenská ulice (kat. č. 1); 2 - Veselá ulice Janáčkovo kulturní centrum (kat. č. 6); 3 - Dominikánská 7 (kat. č. 5); 4 - Česká 6 (kat. č. 2); 5 - Mlýnská ul. (kat. č. 7); 6 - Květinářská ul. (kat. č. 3); 7 - Komárov (kat. č. 8); 8 - Mečová 4 (kat. č. 10); 9 - Panenská ulice (kat. č. 11). Kresba Š. Trávníčková č. 1-4, 8, 9; P. Veselá č. 6, 7 a S. Plchová č. 5.

Abb. 6. Brünner Funde von Bügelkannen mit zoomorphen Ausgüssen. 1 - Panenská-Str. (Kat. Nr. 1); 2 - Veselá-Str. - Janáček Kulturzentrum (Kat. Nr. 6); 3 - Dominikánská-Str. 7 (Kat. Nr. 5); 4 - Česká-Str. 6 (Kat. Nr. 2); 5 - Mlýnská-Str. (Kat. Nr. 7); 6 - Květinářská-Str. (Kat. Nr. 3); 7 - Komárov (Kat. Nr. 8); 8 - Mečová-Str. 4 (Kat. Nr. 10); 9 - Panenská-Str. (Kat. Nr. 11). Zeichnung Š. Trávničková Nr. 1-4, 8, 9; P. Veselá Nr. 6, 7 und S. Plchová Nr. 5. 
variabilní. Ve čtyřech případech můžeme mluvit o transparentní bezbarvé glazuře (kat. č. 1,5 , 7,8 ), objeví se i odstíny tmavě zelené a hnědé (kat. č. 4, 6, 9,10), světle olivově zelená glazura s oranžovými skvrnkami (kat. č. 3) a pro Brno výrazně netypickou se prozatím jeví světle žlutá poleva konvice z České 6 (kat. č. 2). Jediným nepolévaným exemplářem je konvice z Panenské ulice (kat. č. 11).

Dovolují-li dochované nálezy soudit, byly tyto tvary konvic vyrobeny technikou vytáčení na rychle rotujícím hrnčířském kruhu. V ruce tvářené zoomorfní výlevky byly následně na tělo konvic precizně namodelovány.

\section{Zoomorfní výlevky}

V rámci brněnských nálezů výrazně převažují zvířecí výlevky v podobě hlavičky berana (6ks, kat. č. 1-4, 6 a 7), které jsou ztvárněny velmi podobným způsobem. Přibližně uprostřed délky výlevky jsou z plastické pásky namodelovány rohy, jejichž konce bývají mírně zašpičatělé a většinou dosahují až téměř na spodek výlevky. Někdy již částečně nasedají na tělo konvice. Oči bývají umístěny v prostoru napojení rohů. Mohou být plasticky zvýrazněny vtlačeným kroužkem, v jehož středu je drobný důlek ztvárňující oční panenku. Tento drobný detail však například nenacházíme u výlevek třmenové konvice z Panenské ulice (kat. č. 1). Ústí výlevky, tedy zvířecí hubička, bývá mírně rozšířená a jemně dovnitř hraněná.

Tyto výlevky třmenových konvic vykazují zásadní rozdíly oproti aquamanile v podobě beranů, čímž se dají relativně snadno odlišit, jsou-li dochovány právě jen výlevky. ${ }^{8}$

Pouze v prŕípadě hlavičky z benediktinského proboštství v Komárově (kat. č. 9) se s jistotou jedná o jiné zviŕre, které však nejsme schopni jednoznačně určit. Oči jsou ztvárněny stejným způsobem jako u beránků; jediným výrazným atributem tohoto zvířete jsou dlouhé prožlábnuté uši. Stejné zvíře pravděpodobně zpodobňuje stylizovaná výlevka nepolévané konvice z Panenské ulice (kat. č. 11) - ke zvířecí podobě u tohoto exempláře odkazují dlouhé uši zvýrazněné podélnou rýhou. Analogicky k vídeňským nálezům bychom mohli uvažovat o výlevce v podobě zajíce (srov. Huber 2011, 93-94), v úvahu však přichází i liška, pes či prase.

\section{Mimobrněnské nálezy konvic se zvírecími výlevkami}

Nálezy analogických tvarů (obr. 7) jsou dobře známé zvláště z prostoru Dolního Rakouska (Vídeň - Felgenhauer-Schmiedt 1982, 89-91; Huber 2011, 91-101; Perzendorf - Krenn 2011, 149, tab. 106:240-15; ${ }^{9}$ Kremže - Cech 1984, 283-284, obr. 4; Eggenburg - Cech 1987, 193, tab. 71:F1; Huber 2011, obr. 20; Hausleiten - Die Kuenringer, 614, kat. č. 833; St. Pölten - Scharrer-Liška-Scherrer 2010, 29, obr. 11, 12 a 91), kde se objevují v situacích od poloviny 13. století do počátku 14. století. Prozatím starší se jeví konvice s výlevkami v podobě beraní hlavičky, které se také vážou na nižší a „baňatější“ tvary, přičemž o něco mladší konvice s výlevkami v podobě jiných zvířat se objevují na konvicích vyšších a štíhlejších tvarů (Huber 2011, 94-95), byt' nikoliv výlučně.

Také z Bratislavy jsou uváděny polévané konvice se zvířecími výlevkami, datované snad do druhé poloviny 13. až první poloviny 14. století (Hoššo 1997, 288; Hoššo-Lesák 2001, 249; Slivka 1991, 332, kat. č. 4 a obr. 4, tab. IV:3) a několik zajímavých exemplářů pochází z Mad’arska. I zde jsou převážně datovány do druhé poloviny 13. století (obr. 7:11-13; Holl 2005, 321, obr. 6; Parádi 1973, 237, obr. 5).

8 Vedle většinově se objevujícího přesekávání rohů u beránků pocházejících z aquamanile je to především odlišné utváření očí. Oči na brněnských aquamanile v podobě berana jsou ve většině případů ztvárněny tak, že do důlku utvořeného špičatým předmětem je vložena drobná kulička zpodobňující oční panenku a oko je olemováno vtlačeným kroužkem. U aquamanile se nesetkáváme s rozšiřenou a dovnitř mírně hraněnou hubičkou. V místě krku bývá dobře patrný nalévací otvor, přičemž výlevky jsou přímo namodelovány na tělo konvice.

9 V pozn. 495 na straně 149 M. Krenn (2011) uvádí, že od roku 2006 je jich mnoho známo z dolnorakouského Tullnu. 

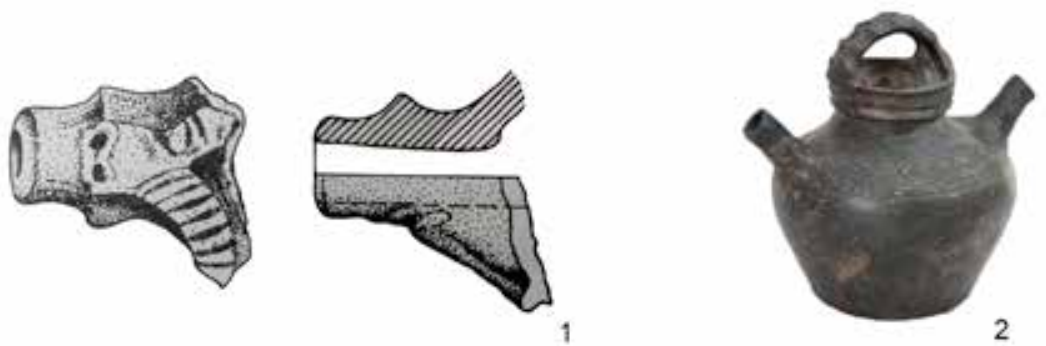

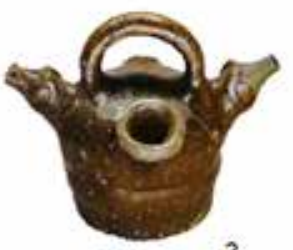

3

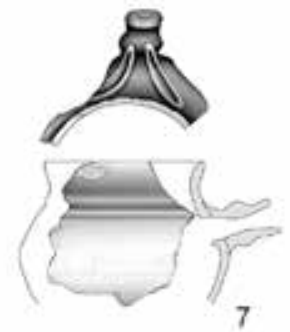

7

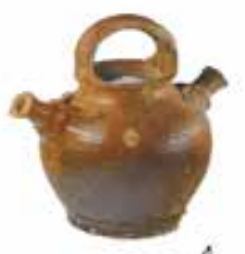

4

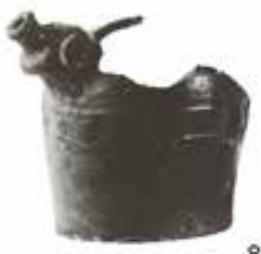

1

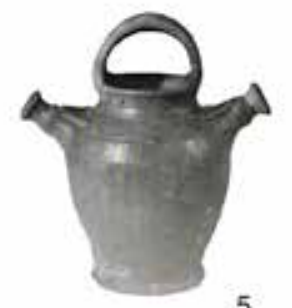

5

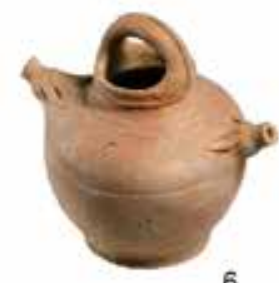

6
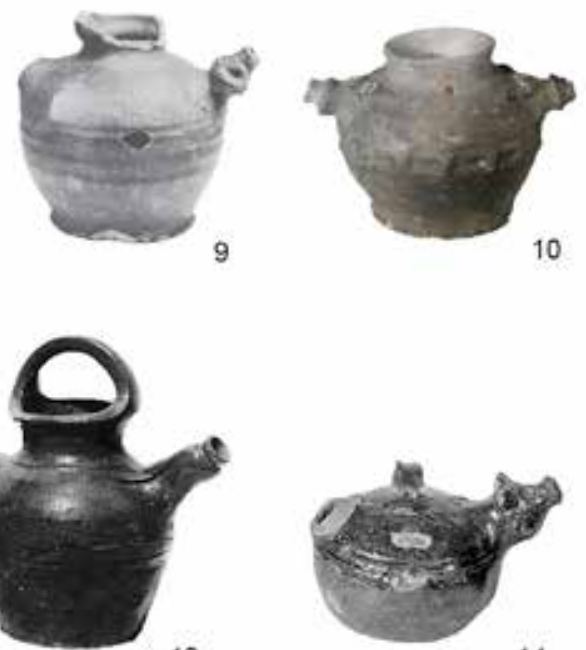

13

Obr. 7. Analogické tvary třmenových konvic se zoomorfními výlevkami. 1 - Koválov (Měřínský-Unger 1987, obr. 36:9); 2 - Plzeň (sbírka Západočeského muzea v Plzni, HA4536, CES on-line); 3-5 Vídeň (Huber 2011, obr. 5, 8 a 9); 6 - St. Pölten (Scharrer-Liška-Scherrer 2010, obr. 11 a 12); 7 - Perzendorf (Krenn 2011, tab. 106); 8 - Kremže (Cech 1984, obr. 4); 9 - Hausleiten (Die Kuenringer, kat. č. 833); 10 - Eggenburg (Huber 2011, obr. 20); 11-13 - Budapešt' (Holl 2005, obr. 6); 14 - Ratiboř (Polsko; Turakiewicz 2010, obr. 4). Rủzná měřítka.

Abb. 7. Analoge Formen von Bügelkannen mit zoomorphen Ausgüssen. 1 - Koválov (Měřínský-Unger 1987, Abb. 36:9); 2 Pilsen (Sammlung des Westböhmischen Museums in Pilsen, HA4536, CES on-line); 3-5 Wien (Huber 2011, Abb. 5, 8 und 9); 6 - St. Pölten (Scharrer-Liška-Scherrer 2010, Abb. 11 und 12); 7 - Perzendorf (Krenn 2011, Taf. 106); 8 - Krems (Cech 1984, Abb. 4); 9 - Hausleiten (Die Kuenringer, Kat. Nr. 833); 10 - Eggenburg (Huber 2011, Abb. 20); 11-13 - Budapest (Holl 2005, Abb. 6); 14 - Raciborz (Polen; Turakiewicz 2010, Abb. 4). Verschiedene Maßstäbe. 
Z Dolního Rakouska a Mad’arska známe dokonce konvice se třemi výlevkami, kterými se zároveň tekutina do konvice nalévala, nebot' některé z těchto konvic nemají okraj, ale jsou v horní části „baňkovitě“ uzavřené (obr. 7:3, 11 a 12). Ze Šoproně by měla pocházet konvice s výlevkou v podobě kentaura, avšak přiřazení tohoto zlomku k figurálním aquamanile se zdá být pravděpodobnější, byt' na základě publikované dokumentace to nelze jednoznačně rozhodnout (Holl 1973, 201, obr. 28:13).

Prozatím však tyto tvary postrádáme $\mathrm{z}$ dalších, nejen jihomoravských lokalit. Výjimkou je nález výlevky v podobě beraní (?) hlavy získané povrchovým sběrem v prostoru zaniklé vsi Koválov (obr. 7:1; Měřínský-Unger 1987, 8-9, obr. 36:9), který se svým ztvárněním nepodobá ani brněnským, ani dolnorakouským nálezům. Relativně malý zlomek výlevky zároveň vzbuzuje jisté pochyby o př́islušnosti právě k tomuto tvaru. Velmi zajímavý je i plzeňský neglazovaný exemplář, který je považován za lampu a časově zařazen do období po polovině 14 . století (obr. 7:2; Orna a kol. 2011, 49-50).

\section{Datování}

K jednoznačnému časovému zařazení třmenových konvic se zoomorfními výlevkami brněnské nálezy neposkytují dostatečných opor. Pokud se tyto nálezy podařilo blíže datovat, byly vždy př́tomny v rámci souborů 14. století, výrazněji v jeho první polovině (kat. č. 5, 6, 9 a 10). Jediný cele dochovaný exemplář (kat. č. 1) byl součástí souboru s keramikou z druhé poloviny 14. až počátku 15. století. Neglazovaná konvice z Panenské ulice (kat. č. 11) byla nalezena ve výplni jímky z druhé poloviny 15 . až první poloviny 16 . století, ale vzhledem $\mathrm{k}$ nálezové situaci nemůžeme vyloučit její vyšší stáŕí. Dnes bohužel nezvěstná konvice z České 5 byla součástí souboru, který měl stejný charakter jako kolekce z jímky s. j. 505, ze které pochází mince Václava II. (1300-1305).

Lze předpokládat, že nejstarší nálezy se na stolech brněnských měštanů začaly př́íležitostně objevovat snad již v závěru 13. století, spíše však až ve století následujícím.

Je samozřejmě otázkou, zda jisté časové opoždění výskytu tohoto tvaru vzhledem $\mathrm{k}$ jeho výskytu v okolních oblastech dolnorakouských, mad’arských i slovenských lze spojovat s pozdější oblibou tohoto tvaru v brněnském prostředí, či je nutno počítat s jejich delším užíváním, kdy mohly být jako cennější předměty chovány v domácnostech po více generací. Jejich delší přežívání $\mathrm{v}$ hmotné kultuře by mohlo např́íklad naznačovat, že nebyly používány každodenně.

\section{Funkční zařazení}

Obdobně jako v okolních oblastech můžeme předpokládat, že tyto konvice byly součástí stolního nádobí tehdejších domácností. Sloužit mohly jak k rozlévání tekutin, tak k umývání rukou - jako aquamanile. Zcela vyloučit však nemůžeme ani možnost, že by se mohlo jednat o konvice na přechovávání vody pro osobní hygienu v měštanských ložnicích, jak mimochodem uvažuje U. Müller (2006, 277). Posledně zmíněnou funkci totiž plnily nejpozději od začátku 15. století závěsné kovové konvice podobných tvarů, které známe ze sbírek mnoha západoevropských muzeí (srov. např. Müller 2006, 273) a jejichž funkční upotřebení právě v oblasti osobní hygieny zobrazují četné ikonografické prameny (obr. 8).

Za jejich možný předstupeň jsou někdy považovány právě exempláře keramické (obr. 9). $\mathrm{K}$ nejstarším patří nález konvičky z Basileje, datované do období druhé poloviny 13. století až první poloviny 14. století (obr. 9:4; Keller 1999, 76-77; 1999a, tab. 5:1) či konvička z holandské hradní lokality Nieuwburg u Alkmaaru datovaná do let 1290-1300 (obr. 9:3; Janssen 1983, 141, obr. 9.6.3). Pravděpodobně do stejného okruhu konvic patř́i i nález z Mostu (obr. 9:2; Klápště 1998, obr. 4a:1) a snad i konvička z Drážd’an (obr. 9:1; Krabath 2012, 67, obr. 43:2).

Zda i konvice se zoomorfně ztvárněnými výlevkami z oblasti středního Podunají představují předstupeň kovových exemplářů, můžeme dnes již jen spekulovat. Mohly by být dokonce starší než výše zmíněné exempláře ze Švýcarska a Holandska. Vývoj spějící k závěsným tvarům 


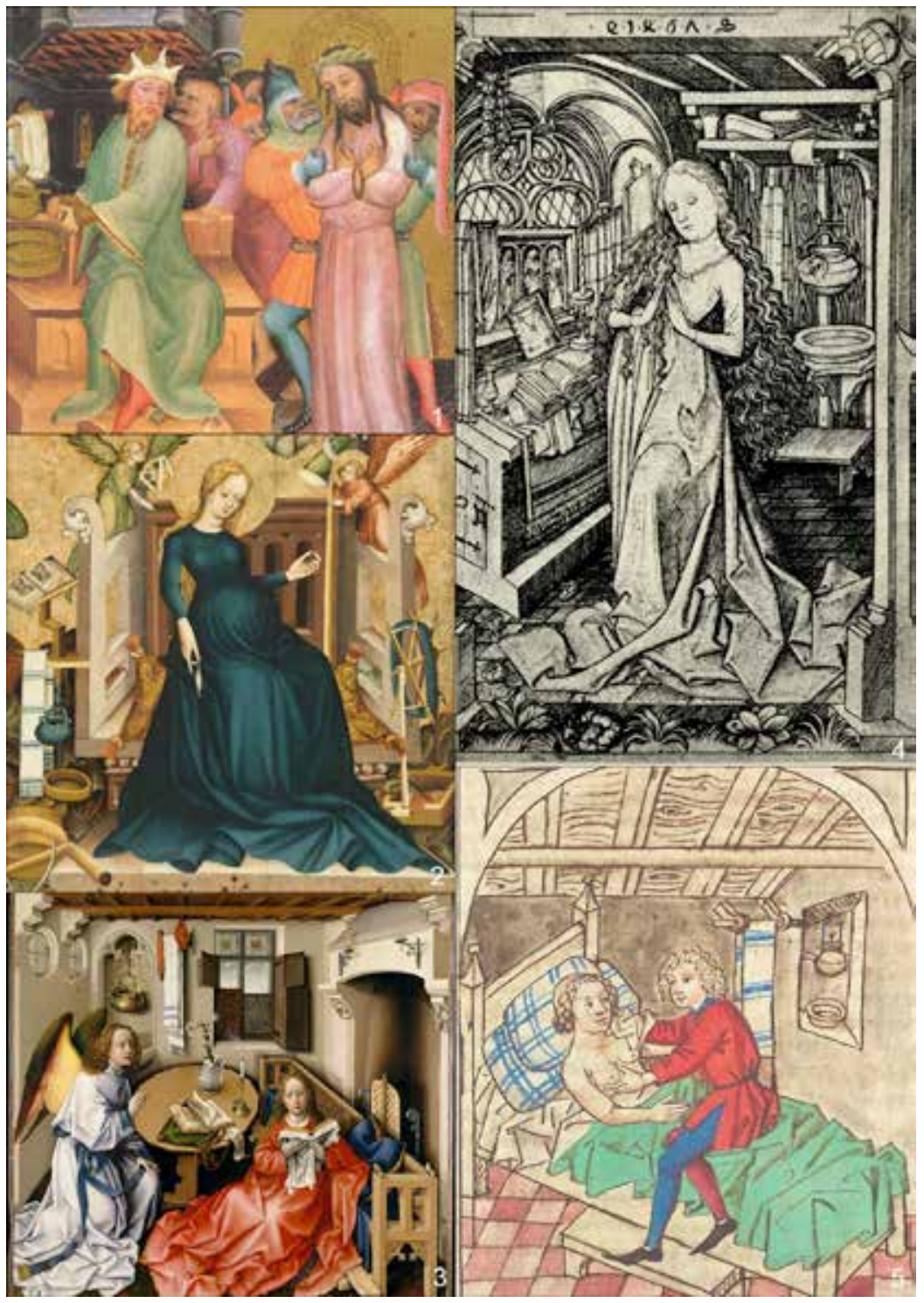

Obr. 8. Ikonografické doklady kovových (?) závěsných konviček. 1 - Výřez z Pašijového oltáře s motivem Krista před Pilátem, Mistr Bertram z Mindenu, kolem 1390, Niedersächsisches Landesmuseum Hannover; 2 - Panna Marie v očekávání z Németújváru (dnešní Güssing, Rakousko), kolem 1410, Magyar Némzeti Galéria, inv. č. 52.656; 3 - Oltář z Merode, dílna Roberta Campina, kolem 1427-1432, Holandsko, Metropolitan Museum of Art, inv. č. 56.70a-c; 4 - Modlící se Panna Marie ve svém pokoji, Albertina Museum, 1467, inv. č. DG1926/697; 5 - Antonius von Pforr, Buch der Beispiele, Švábsko, kolem 1480-1490, Univerzitní knihovna v Heidelbergu, Cod. Pal. germ. 85, fol. 128r.

Abb. 8. Ikonographische Belege von Lavabokesseln aus Metall (?). 1 - Ausschnitt aus dem Passionsaltar mit dem Motiv Christus vor Pilatus, Meister Bertram aus Minden, um 1390, Niedersächsisches Landesmuseum Hannover; 2 - Maria in Erwartung aus Németújvár (heute Güssing, Österreich), um 1410, Magyar Némzeti Galéria, Inv.-Nr. 52.656; 3 - Altarbild von Mérode, Werkstatt von Robert Campin, um 1427-1432, Holland, Metropolitan Museum of Art, New York, Inv.-Nr. 56.70a-c; 4 - Die betende Jungfrau Maria in ihrem Gemach, Albertina Museum, 1467, Inv.-Nr. DG1926/697; 5 - Antonius von Pforr, Buch der Beispiele, Schwaben, um 1480-1490, Universitätsbibliothek in Heidelberg, Cod. Pal. germ. 85, fol. 128r. 


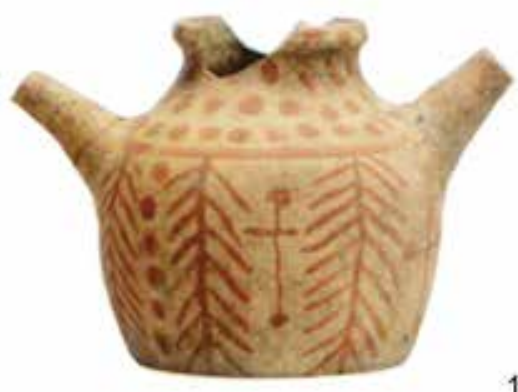

1

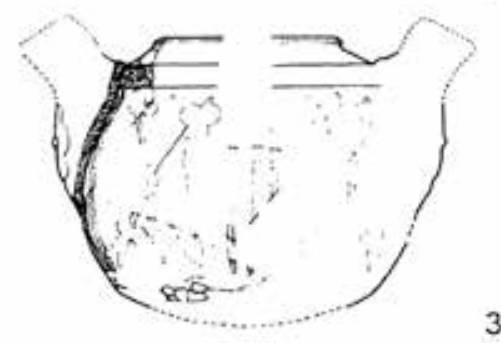

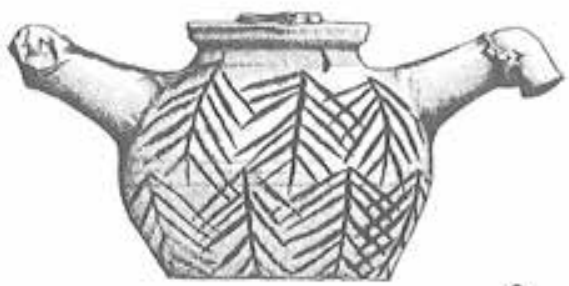

2

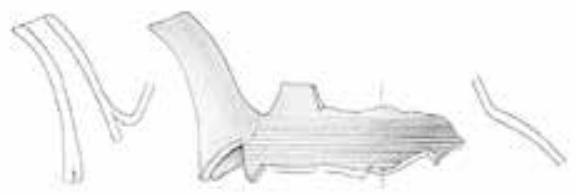

4

Obr. 9. Nejstarší doklady stojících i závěsných (?) keramických konviček. 1 - Drážd’any (Německo; Krabath 2012, obr. 43:2); 2 - Most (Klápště 1998, obr. 4a:1); 3 - Nieuwburg u Alkmaaru (Holandsko; Janssen 1983, obr. 9.6.3); 4 - Basilej (Švýcarsko; Keller 1999b, tab. 5:1). Různá měřítka.

Abb. 9. Die ältesten Belege von Lavabokesseln (?) aus Keramik. 1 - Dresden (Deutschland; Krabath 2012, Abb. 43:2); 2 Most (Klápště 1998, Abb. 4a:1); 3 - Nieuwburg bei Alkmaar (Holland; Janssen 1983, Abb. 9.6.3); 4 - Basel (Schweiz; Keller 1999b, Taf. 5:1). Unterschiedliche Maßstäbe.

dobře dokumentuje konvice datovaná do 14. století z dolnorakouského Eggenburgu (obr. 7:10; Cech 1987, 193, tab. 71:F1), která již postrádá třmenové ucho. Dva protilehlé otvory na hrdle nádoby nás nenechávají na pochybách, že tato konvice mohla být původně zavěšena. K zavěšení (?) je dobře uzpůsobena i konvička z polské Ratiboře s původně dvěma (?) zoomorfně ztvárněnými výlevkami s datací nově nejdříve do druhé poloviny 14. století (obr. 7:14; Turakiewicz 2010, 144-145, obr. 4; Marethová-Turakiewicz-Zezula 2018, 213-214).

Stejné funkční uplatnění musely mít i nálezy z Německa, Holandska a Belgie objevující se ve 14. a 15. století. Je však velmi těžké říci, zda se ještě jedná o „předchůdce“, nebo o levnější imitace kovových závěsných cisteren (obr. 10; Müller 1996, obr. 10; 2006, 275, obr. 84:2-4). Zde již nenacházíme třmenové ucho, jež bylo bezpochyby slabým článkem těchto nádob a bylo nahrazeno dvěma protilehlými uchy nebo speciálními výčnělky s otvory, skrze které mohly být zavěšeny. Spojitost s našimi konvicemi se zoomorfními výlevkami dobře dokumentuje závěsná konvička z Utrechtu, jejíž dvě výlevky jsou formovány do podoby zvířecí hlavičky, ne nepodobné podunajským exemplářům s dlouhými prožlábnutými uchy (obr. 10:1).

Tvarovou rozmanitost pravděpodobně funkčně stejného tvaru dokumentují i další nálezy keramických závěsných konvic, jejichž výlevky mají v některých př́ípadech také podobu zvířecí hlavičky. Ty se objevují v rozsáhlém prostoru od Švýcarska po severní Německo, byt’ pouze v jednotlivých exemplářích (obr. 11; srov. Müller 2006, 277, obr. 85:3-5; většinu známých nálezů uvádí Kluttig-Altmann 2006, 285-287, obr. 189-191). Jejich dlouhý časový výskyt, od 14. do 16. století, nedovoluje jednoznačně usoudit, zda by se mohlo jednat o předchůdce kovových závěsných cisteren, jejich levnější (?) nápodobu, nebo o zcela samostatný keramický tvar.

Co ovšem v brněnských archeologických nálezech prozatím postrádáme, jsou nádoby na zachytávání vody, které je nutné předpokládat při užívání konvic pro osobní hygienu i ve funkci 
1
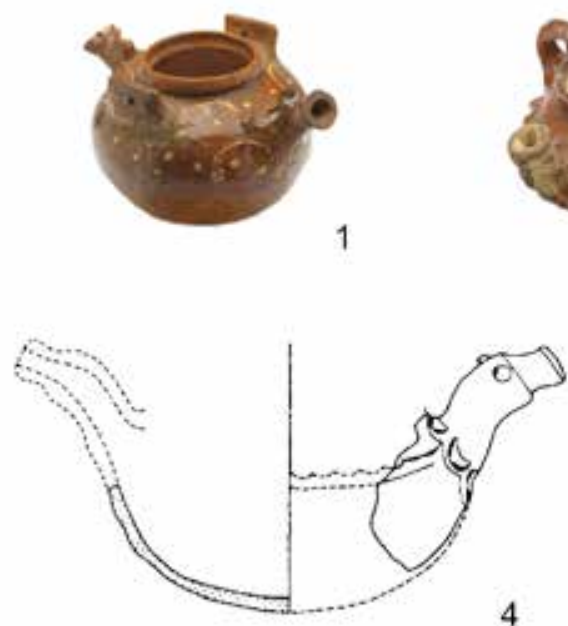

2

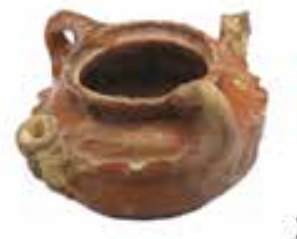

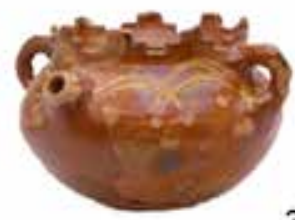

3

Obr. 10. Keramické závěsné konvice datované do 14.-15. století. 1 - Utrecht (Holandsko; Museum Boijmans van Beuningen); 2 - Leiden (Holandsko; Museum Boijmans van Beuningen); 3 - Dordrecht (Holandsko; Museum Boijmans van Beuningen); 4 - Lübeck (Německo; Müller 2006, obr. 84:2); 5 - Oldenburg (Německo; Fansa 1988, obr. 31). Rủzná měřítka.

Abb. 10. Ins 14.-15. Jhdt. datierte Lavabokessel aus Keramik. 1 - Utrecht (Holland; Museum Boijmans van Beuningen); 2 - Leiden (Holland; Museum Boijmans van Beuningen); 3 - Dordrecht (Holland; Museum Boijmans van Beuningen); 4 - Lübeck (Deutschland; Müller 2006, Abb. 84:2); 5 - Oldenburg (Deutschland; Fansa 1988, Abb. 31). Unterschiedliche Maßstäbe.
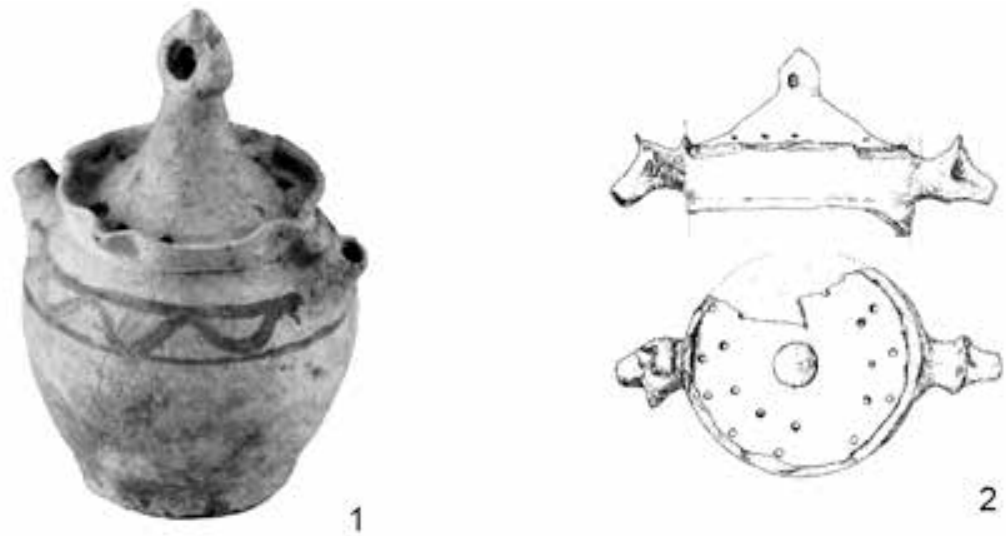

1

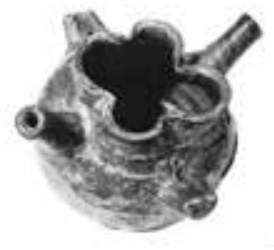

3
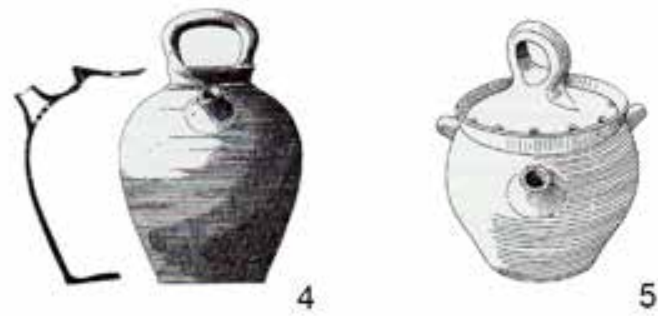

Obr. 11. Další tvary závěsných konvic ve funkci lavaba. 1 - Řezno (Německo; Kluttig-Altmann 2006, obr. 191); 2 - Cvikov (Německo; Kluttig-Altmann 2006, obr. 189); 3 - Kolín nad Rýnem (Německo; Museum für Angewandte Kunst Köln); 4 Schmallfelden (Německo; Müller 2006, obr. 85:4); 5 - Stetten (Německo; Müller 2006, 84:5). Rủzná měřítka.

Abb. 11. Weitere Formen von Lavabokesseln. 1 - Regensburg (Deutschland; Kluttig-Altmann 2006, Abb. 191); 2 - Zwickau (Deutschland; Kluttig-Altmann 2006, Abb. 189); 3 - Köln am Rhein (Deutschland; Museum für Angewandte Kunst Köln); 4 - Schmallfelden (Deutschland; Müller 2006, Abb. 85:4); 5 - Stetten (Deutschland; Müller 2006, 84:5). Unterschiedliche Maßstäbe. 
aquamanile. Jako nejvhodnější se jeví tvar mísy. S možnými exempláři se však setkáváme až od druhé poloviny 14., spíše v první polovině 15 . století. Kromě klasických redukčně pálených kónických mís, nejčastěji s vodorovně vyloženým okrajem, jsou to nižšś glazované mísy, často opatřené radélkovým dekorem na okraji (Procházka 1996, 328, 330-331; např. Dominikánská 15a, obj. 538 - Procházka 2013, 65; Mečová 2, obj. 9, inv. č. 427824 a obj. 4, inv. č. 421744 Kováčová 2006). V době jejich užívání ovšem v nálezech již absentují výše zmíněné konvice.

Naše nálezy prozatím nepodporují funkci osvětlovadla, nebot’ žádná z dokumentovaných výlevek nenese stopy po očazení. V německém prostředí jsou však obdobné nálezy jako lampy interpretovány.

\section{Symbolika}

Zajímavá je obliba výlevek v podobě beraní hlavičky, která je mimochodem v brněnském prostředí charakteristická i pro aquamanile, byt' její ztvárnění se u obou tvarů stylově odlišuje. Pozadí tohoto jevu nám prozatím uniká a je nutné se spokojit s konstatováním, že zpodobení berana bylo v Brně velmi populární.

I přes nezpochybnitelné profánní užití těchto nádob nemůžeme současně pominout možný hlubší význam zobrazovaných zvířat - a to v kontextu křest’anské symboliky, v níž zvířata hrála nezanedbatelnou roli.

Nejčastěji zobrazovaný beránek má ve středověké symbolice mnoho významů, a i když se samotná symbolika mohla $\mathrm{v}$ čase měnit, můžeme beránka považovat především za ztělesnění Ježíše Krista (Agnus Dei), který se obětoval za odpuštění lidských hříchů. Pro středověkého člověka tak mohl beránek představovat pokoru, čistotu a nevinnost (Royt-Šedinová 1998, 154-155; Heinz-Mohr 1999, 32-33). Právě onu symboliku čistoty - at' již šlo o omývání rukou, či jiných částí těla - tyto konvice dobře splňují, nebot' proléváním vody skrze hrdlo beránka v sobě spojují jak očistu fyzickou, tak i duchovní.

U druhého typu výlevek nejsme vzhledem k absenci výrazných atributů schopni říci, o jaké zvíře se jedná, tudíž nám jeho symbolika zcela uniká. Stejně jako u beránků lze předpokládat kladný význam tohoto zvířete, pravděpodobně také ve spojitosti s očistou.

\section{Nálezové prostředí}

Přestože dosud známé nálezy odkazují do prostředí měštanských domácností, ojedinělý nález z prostoru zaniklé vsi Koválov, ale i například rakouského Perzendorfu ukazují, že tyto předměty nemusely být neznámé ani ve vesnickém prostředí. Nález z prostoru benediktinského kláštera v Brně-Komárově sice odkazuje k církevnímu prostředí, jeho spojení s liturgií je však jen těžko prokazatelné.

\section{Provenience}

Pro období výskytu třmenových konvic se zoomorfními výlevkami, tedy závěr 13. a první polovinu 14. století, jsou to v Brně právě jen tyto tvary, miniaturní nádobky, aquamanile a ojedinělé bohatě zdobené džbány, jejichž povrch je opatřen glazurou. Z tohoto důvodu jsou tyto výrobky považovány většinou za importované.

Materiálový průzkum keramické hmoty ${ }^{10}$ části vzorků (kat. č. 1, 2, 3 a 6) však naznačuje, že by se minimálně ve třech prŕípadech mohlo jednat o výrobky místních hrnčírư. Vzorek třmenové konvice $\mathrm{z}$ Panenské ulice (kat. č. 1) obsahuje úlomky metabazaltů tvořené rubifikovanými amfiboly a chlority, které se v Brně vyskytují na svazích Petrova a objevují se v hmotě kachlů

10 Materiálový průzkum byl proveden mikropetrografickým rozborem, díky němuž lze z keramického artefaktu získat co nejvíce poznatků, at již jde o základní představu o jeho užitné hodnotě, nebo o možnost na základě specifických znalostí vyvodit závěry o použitých surovinách. Mikroskopie výbrusového preparátu keramického stř̌epu nám poskytuje základní informace o zastoupení úlomků minerálů a hornin, teplotách výpalu a změnách realizujících se v keramických artefaktech během dlouhodobé depozice v antropogenních půdních horizontech (Gregerová a kol. 2010). Výbrusové preparáty třmenových konvic byly analyzovány polarizačním mikroskopem Olympus BX 51 . 
z rytířských kamen (Hložek-Jordánková-Loskotová 2018, 495). Další dva analyzované vzorky z Květinářské (kat. č. 3) a Veselé ulice (kat. č. 6) jsou třmenové konvici z Panenské ulice zastoupením úlomků minerálů a hornin blízké, ale neobsahují úlomky amfibolů. Přesto je možné předpokládat, že i tyto exempláře mohly být vyrobeny z hlíny získávané v Brně nebo blízkém okolí. Zajímavostí je, že v jejich ostřivu lze zaznamenat drt' keramických střepů. Od těchto tří vzorků se odlišuje keramická hmota třmenové konvice z České 6 (kat. č. 2), která byla zhotovena z kaolínové suroviny pálící se do bílých odstínů. K možné provenienci posledně zmíněné konvice však mikropetrografický rozbor nepřinesl potřebné informace.

Zajímavé je i srovnání brněnských nálezů s výlevkami v podobě beraních hlaviček s publikovaným materiálem, při němž nelze nevidět jisté stylové odlišnosti. Nápadnou skupinu pozorujeme ve vídeňském prostředí, kde výlevky v podobě beránků mají výrazně zduřelou hlavu a mohutně klenuté rohy a vylévací otvor nebývá rozšířený a hraněný (obr. 7:3). Vzhledem k velkému množství nálezů se předpokládá jejich místní původ (Huber 2011, 91-101). Odlišně působí i nálezy v oblastech západně Vídně, které reprezentují konvice s kulovitým tělem - beránci na nich mají výrazně zatočené rohy (Hausleiten, Kremže; obr. 7:8 a 9). Ve srovnání s dolnorakouskými nálezy jsou těla, ale i samotné výlevky brněnských konvic subtilnější a vylévací otvor bývá rozšiřený a hraněný. Posledně zmíněný znak však již nacházíme u výlevek v podobě zajíce, které jsou stylově velmi rozmanité. Jak dokládá nález z dolnorakouského St. Pölten, alespoň některé z nich byly vyráběny právě zde (Scharrer-Liška-Scherrer 2010, 29-30, 99-100). Brněnské nálezy by tak mohly odkazovat $\mathrm{k}$ odlišné dílně, byt' inspirace vídeňskými nálezy je nepopiratelná. Otázkou zůstávají nálezy mad’arské, které jsou již tradičně považovány za rakouský import (Holl 2005, 321).

Myšlenka, že i v Brně byly vyráběny tyto zajímavé a v porovnání s běžnou keramickou produkcí technologicky vyspělé konvice, je nám značně sympatická a domníváme se, že tomu tak opravdu bylo. Budoucím výzkumem bude nutné ověřit, zda i další glazované výrobky tohoto období nemohou mít alespoň z části místní původ.

\section{Závěr}

Třmenové konvice patří na jižní Moravě k nejranějším projevům kulturních vlivů z rakouského Podunají, které jsme schopni v tehdejší keramické produkci rozpoznat, byt' četnost nálezů není nijak závratná.

$\mathrm{S}$ „klasickými“" tvary těchto konvic se v Brně setkáváme již před polovinou 13. století a během první poloviny 14. století se z nálezových souborů pomalu vytrácí. Nejpozději v závěru 13. století se tvar třmenové konvičky stává oblíbeným i v rámci miniaturních nádobek, a to jak $\mathrm{v}$ režném, tak i glazovaném provedení. Zároveň se v nálezech objevuje i zcela specifický keramický tvar třmenové konvice se dvěma zoomorfně ztvárněnými výlevkami, nejčastěji v podobě beraní hlavičky. Je však otázkou, zda lze za předchůdce těchto tvarů považovat „klasické“ třmenové konvice. Spíše se asi jedná o zcela samostatný keramický tvar, který se v závěru 13. století stal součástí stolního nádobí a pravděpodobně patřil do okruhu nádob označovaných jako aquamanile. Jejich užití jako závěsných cisteren na vodu v měštanských domech přichází na mysl při srovnání s kovovými exempláři, které se $\mathrm{v}$ západoevropském prostředí hojně objevují zvláště od 15. století. Námi studované exempláře se však od těchto cisteren odlišují pozicí ucha, které je většinově umístěno v ose výlevek, což bezpochyby usnadňovalo manipulaci při nalévání, a dochovaná třmenová ucha nenesou stopy mechanického opotřebení po zavěšení.

U „klasických“ třmenových konvic nepochybujeme, že byly vyráběny místními hrnčírii. U glazovaných miniaturních konviček nejsme za dnešního stavu poznání schopni říci, zda mohly být vyráběny místními hrnčíři, či zda se jedná o zboží dovážené. Mikropetrografické rozbory keramické hmoty tř́i konvic se zoomorfními výlevkami (kat. č. 1, 3 a 6) naznačují, že alespoň část těchto konvic nalézaných v Brně mohla být vyráběna místními hrnčíři, případně hrnčíři v blízkém okolí. Tento předpoklad podporuje i poněkud odlišné stylistické pojetí brněnských 
konvic vzhledem k exemplářům dolnorakouským. Lze se domnívat, že právě nálezy dolnorakouské byly zdrojem inspirace pro místní výrobky.

Společně s aquamanile a miniaturními nádobkami se tyto konvice staly nejpozději na počátku 14. století součástí vybavení domácností brněnských měšt’anů, které doplňovalo, někdy možná nahrazovalo luxusní nádobí kovové a skleněné. Jejich určitá reprezentativnost je dána faktem, že kromě aquamanile, miniaturních nádobek a několika málo vně polévaných džbánů se $\mathrm{s}$ glazovanými výrobky $\mathrm{v}$ tomto období v Brně téměř nesetkáváme. Zároveň jsou tyto konvice zajímavým dokladem zvyšující se úrovně kultury stolování a bydlení, i zvyšujících se hygienických nároků společnosti středověkého města.

Článek byl podpořen projekty: „Vrcholně středověká keramika jako součást movitého kulturního dědictvi““ v programu Ministerstva kultury na podporu aplikovaného výzkumu a experimentálního vývoje národní kulturní identity (NAKI II), identifikační kód projektu DG18P02OVV020, a „Zdroje a šíření vybraných komodit keramické produkce vrcholného a pozdního středověku“, identifikační kód projektu GA17-13967S.

\section{Katalog}

\section{1) Panenská ulice}

k. ú. Město Brno, parc. č. 619/1, výzkum Archaia Brno (A014/2009), odpadní jímka s. j. 772=1662 (výplı̌s. j. 4302), bez inv. ̌́.

Téměř celá třmenová konvice se dvěma výlevkami v podobě hlaviček beránků. Chybí pouze polovina dna.

V obecném pohledu se jedná o vejčitý tvar s výrazně profilovaným hrdlem. Římsovitý okraj je na vnější straně zdoben dvěma rýhami. Další dvě rýhy jsou umístěny na přechodu hrdla a plecí. Pod maximální výdutí pozorujeme drobnou rýhu a odsazení.

Třmenové ucho vychází z okraje a je umístěno v ose výlevek. Průřez ucha je mírně oválný, ucho je uprostřred (v nejvyšším bodě) zdobeno vtlačeným kroužkem o průměru $8-9 \mathrm{~mm}$. Dno nenese stopy po odříznutí.

Obě výlevky jsou ve své základní formě totožné, liší se jen v drobných detailech, které jsou při technice modelování z ruky samozřejmé. Plasticky modelované rohy jsou zatočeny až na spodní stranu výlevky. U jedné výlevky jsou rohy již částečně namodelovány na tělo konvice. Oči jsou zvýrazněny jen vtlačeným kroužkem. Ústí výlevek se mírně rozšiřují.

Keramické těsto je vypálené do cihlové barvy a na vnějším povrchu pokryto transparentní glazurou, která přesahuje i na vnitřní okraj nádoby, a její kapičky najdeme i uvnitř nádoby. Dno je též glazováno.

Výška nádoby: $205 \mathrm{~mm}$ (bez ucha $145 \mathrm{~mm}$ )

Průměr okraje/dna: 90/95 mm

Vnitřní průměr vylévacího otvoru: $8 \mathrm{~mm}$

Datace: 2. polovina 14 . - počátek 15 . století

Lit.: Holub-Staněk 2009-2014

Uloženo: Muzeum města Brna

Obr. 5:1 a 6:1

\begin{tabular}{|l|l|}
\hline Označení vzorku & Panenská ulice (A014/2009) - jímka s. j. 772=1662 (výplň s. j. 4302) \\
\hline Charakteristika střepu & keramika ze sprašové hlíny s glazovaným povrchem \\
\hline Zrnitost & velmi jemná \\
\hline
\end{tabular}




\begin{tabular}{|c|c|}
\hline Porozita & $6 \%$ \\
\hline Pojivo & homogenní \\
\hline Mikrostruktura & všesměrná \\
\hline Hlavní složky & $\begin{array}{l}\text { ostřivo } 39 \% \\
\text { pojivo } 55 \% \\
\text { porozita } 6 \%\end{array}$ \\
\hline Modální složení & $\begin{array}{l}\text { Úlomky minerálů: křemen, biotit, muskovit, akcesoricky plagioklasy, alkalické živce. } \\
\text { Vzácně se vyskytují střípky rubifikovaných amfibolů. } \\
\text { Úlomky hornin: křemence, metakvarcity, kataklazity a ojedinělé úlomky metabazaltů, } \\
\text { slínitých hornin a silicitů. }\end{array}$ \\
\hline $\begin{array}{l}\text { Mikropetrografický } \\
\text { rozbor }\end{array}$ & $\begin{array}{l}\text { Křemen tvoří nepravidelně omezená až stř́ípkovitá zrnka. } \\
\text { Živce jsou obvykle ostrohranné až poloostrohranné s náznaky tabulkovitých průřezů. } \\
\text { Vzácně jsou nepřeměněné, nejčastěji bývají kaolinitizované a sericitované. } \\
\text { Bezbarvý muskovit spolu s rezavě hnědým biotitem jsou součástí pojiva, velmi vzácně } \\
\text { se vyskytují jejich větší tabulky v ostřivu. } \\
\text { V pojivu lze identifikovat stř́ípky rubifikovaných amfibolů. } \\
\text { Z úlomků hornin byly identifikovány křemence, metakvarcity, kataklazity a velmi } \\
\text { vzácné úlomky metabazaltů. Křemence jsou tvořeny izometrickými nerovnoměrně } \\
\text { zrnitými křemeny, místy obsahují oxyhydroxidy Fe. } \\
\text { Metakvarcity jsou složeny z drobných protáhlých útvarů křemene, které jsou místy } \\
\text { prostoupeny sericitem. Místy se vyskytují klasty kataklazitů s nápadnými undulózně } \\
\text { zhášejícími křemeny. Vzácně se vyskytují úlomky metabazaltů tvořené rubifikovaný- } \\
\text { mi amfiboly a chlority, které doprovázejí zrnka epidotů. V nepravidelných pórech je } \\
\text { př́itomen sekundární karbonát. Velmi vzácně lze identifikovat úlomky silicitů a slíni- } \\
\text { tých hornin. }\end{array}$ \\
\hline Poznámka & $\begin{array}{l}\text { Teplota výpalu, stanovená pouze podle zbarvení artefaktu, je pravděpodobně vyšší } \\
\text { než } 900^{\circ} \mathrm{C} \text {. }\end{array}$ \\
\hline
\end{tabular}

\section{2) Česká 6}

k. ú. Město Brno, parc. č. 543, výzkum Archaia Brno (A094/2012), inv. č. 1146/3, nestratifikované nálezy

Přibližně polovina třmenové konvice $\mathrm{s}$ jednou dochovanou výlevkou v podobě hlavičky beránka. Rohy beránka jsou namodelovány přibližně ve středu výlevky a zatočeny jsou téměř až na její spodek. Oči jsou plasticky ztvárněny důlkem, který je olemován vtlačeným kroužkem v místě namodelování rohů. Vylévací otvor se jen nepatrně rozšiřuje.

Tvar těla konvice lze popsat jako mírně baňatý. Okraj je střechovitě seříznutý, přechod hrdla v plece je zvýrazněn drobným žlábkem. Třmenové ucho bylo umístěno v ose výlevek, jak dokládají stopy po odlomení na okraji konvice v místě nad dochovanou výlevkou. Výlevka je na tělo nádoby namodelována $\mathrm{v}$ prostoru maximální výdutě nádoby.

Keramické těsto je vypáleno do bílých odstínů a opatřeno žlutou glazurou. Ta je místy zbarvena do kovově šedé až černé barvy, což je pravděpodobně způsobeno podmínkami uložení. Glazura je četně zatečena i do vnitřku konvice.

Dochovaná výška nádoby: $100 \mathrm{~mm}$

Vnitřní průměr vylévacího otvoru: $10 \mathrm{~mm}$

Datace: nelze datovat (nestratifikované nálezy)

Lit.: Staněk-Peška 2014

Uloženo: dočasně depozitář Archaia Brno

Obr. 5:2 a $6: 4$ 


\begin{tabular}{|l|l|}
\hline Označení vzorku & Česká 6 (A094/2012), inv. č. 1146/3 \\
\hline Charakteristika střepu & keramika zhotovená z kaolínu \\
\hline Zrnitost & velmi jemná \\
\hline Porozita & $4 \%$ \\
\hline Pojivo & heterogenní \\
\hline Mikrostruktura & paralelní \\
\hline Hlavní složky & $\begin{array}{l}\text { ostřivo } 35 \% \\
\text { pojivo } 61 \% \\
\text { porozita } 4 \%\end{array}$ \\
\hline Modální složení & $\begin{array}{l}\text { Úlomky minerálů: křemen, biotit, muskovit, mullit. } \\
\text { Úlomky hornin: neidentifikovány. }\end{array}$ \\
\hline $\begin{array}{l}\text { Mikropetrografický } \\
\text { rozbor }\end{array}$ & $\begin{array}{l}\text { Křemen tvoří ostrohranné až poloostrohranné úlomky. } \\
\text { Živce nejsou rozpoznatelné. } \\
\text { Bezbarvý muskovit je velmi jemně lupenitý. Rezavě hnědé jsou ojedinělé lupínky } \\
\text { biotitu. } \\
\text { Artefakt je prostoupen jemnými sloupečkovitými krystalky mullitu (jeho př́tomnost } \\
\text { potvrzena i pomocí XRD). }\end{array}$ \\
\hline Poznámka & Výchozí surovinou byl kaolín. Teplota výpalu 1050-1100 ${ }^{\circ} \mathrm{C}$. \\
\hline
\end{tabular}

\section{3) Květinářská - divadlo Reduta}

k. ú. Město Brno, parc. č. 398, výzkum Archaia Brno (A030/2002), inv. č. 218/3, 204/48 a 49, s.j. 500

Dvě výlevky v podobě hlaviček beránků a zlomek obloukovitého držadla. Přestože jedna z výlevek pochází z jiného kontextu než zbylé dva zlomky, je vzhledem k velké podobnosti keramického těsta i glazury pravděpodobné, že původně patřily $\mathrm{k}$ jedné nádobě.

Obě výlevky jsou ve své základní formě totožné, liší se jen v drobných detailech, které jsou při technice modelování z ruky samozřejmé.

Větší z výlevek (inv. č. 218/3) je odlomena v místech připojení k tělu vytáčené nádoby. Přibližně uprostř̌ed délky obou výlevek jsou namodelovány rohy. Ty jsou výrazně zatočené a dosahují téměř až na spodek výlevky. V místě napojení rohů jsou plasticky zvýrazněny oči - panenky jsou utvořeny drobnými důlky a olemovány koncentrickými kroužky. Zlomek třmenového ucha je mírně oválného průřezu.

Střep výlevek je vypálen do cihlové barvy, při povrchu místy přechází do světle šedé barvy (tzv. sendvičový efekt). Pouze ucho konvice je vypáleno do světle šedé barvy. Všechny zlomky jsou pokryté světle olivově zelenou glazurou s oranžovými skvrnkami.

Vnitřní průměr vylévacího otvoru: 14 mm (inv. č. 218/3) a 12 mm (inv. č. 204/49)

Datace: blíže nedatováno

Lit.: Veselá 2003, kat. č. 42 a 43

Uloženo: Muzeum města Brna

Obr. 5:5 a 6:6

\begin{tabular}{|l|l|}
\hline Označení vzorku & Květinářská - divadlo Reduta (A030/2002), inv. č. 204/48 \\
\hline Charakteristika střepu & keramika ze sprašové hlíny s glazovaným povrchem \\
\hline Zrnitost & jemná s ojedinělými většími úlomky v ostřivu \\
\hline Porozita & $5 \%$ \\
\hline
\end{tabular}




\begin{tabular}{|c|c|}
\hline Pojivo & homogenní \\
\hline Mikrostruktura & všesměrně zrnitá \\
\hline Hlavní složky & $\begin{array}{l}\text { ostřivo } 45 \% \\
\text { pojivo } 50 \% \\
\text { porozita } 5 \%\end{array}$ \\
\hline Modální složení & $\begin{array}{l}\text { Úlomky minerálů: křemen, biotit, muskovit, akcesoricky plagioklasy a alkalické } \\
\text { živce. } \\
\text { Úlomky hornin: ojedinělé slídové břidlice, křemence, metakvarcity, kataklazity, } \\
\text { Fe-oxyhydroxidy, úlomky starší keramiky. }\end{array}$ \\
\hline $\begin{array}{l}\text { Mikropetrografický } \\
\text { rozbor }\end{array}$ & $\begin{array}{l}\text { Křemen tvoří nepravidelně omezená až střípkovitá zrnka. } \\
\text { Živce se vyskytují sporadicky. Obvykle jsou ostrohranné až poloostrohranné s názna- } \\
\text { ky tabulkovitých průřezů. Jsou čiré i přeměněné. V produktech přeměn se vyskytují } \\
\text { jílové minerály a sericit. } \\
\text { Bezbarvý muskovit spolu s rezavě hnědým biotitem jsou součástí pojiva, velmi vzácně } \\
\text { se vyskytují jejich větší tabulky v ostřivu. Muskovit bývá podstatnou součástí horni- } \\
\text { nových úlomků - sericitových břidlic. } \\
\text { Z úlomků hornin byly identifikovány křemence, metakvarcity, kataklazity a slídové } \\
\text { (sericitové) břidlice. Křemence jsou tvořeny izometrickými nerovnoměrně zrnitými } \\
\text { křemeny, místy obsahují Fe-oxyhydroxidy. } \\
\text { Metakvarcity jsou složeny z drobných protáhlých útvarů křemene, které jsou místy } \\
\text { prostoupeny sericitem. Vzácně se vyskytují klasty kataklazitů. } \\
\text { Na modálním složení slídových břidlic se podílejí muskovit a křemen. Lupínky mus- } \\
\text { kovitu jsou bezbarvé velmi jemně šupinkaté. } \\
\text { Součástí suroviny byly Fe-bročky a rozpoznatelné jsou okrouhlé útvary starší kerami- } \\
\text { ky, surovinově shodné s hodnoceným artefaktem. }\end{array}$ \\
\hline Poznámka & $\begin{array}{l}\text { Výchozí surovina je sprašová hlína. Obsahuje úlomky starší keramiky. Teplota výpalu } \\
\text { kolem } 850-950^{\circ} \mathrm{C} \text {. }\end{array}$ \\
\hline
\end{tabular}

\section{4) Koliště}

k. ú. Zábrdovice, parc. č. 637/1, výzkum Archaia Brno (A064/2004), inv. č. 110/30 (sb. č. 353166), nestratifikované nálezy

Výlevka v podobě hlavičky beránka a zlomek jedné další, jejichž vzájemná podobnost dovoluje uvažovat o možnosti, že by mohly pocházet $\mathrm{z}$ jedné nádoby.

Lépe dochovaná výlevka je odlomena v místě napojení na tělo nádoby. Přibližně uprostřed délky výlevky jsou namodelovány zatočené rohy, jejichž konce dosahují až téměř na spodek výlevky. Oči jsou plasticky ztvárněny důlkem, který je olemován vtlačeným kroužkem v místě napojení rohů. Vylévací otvor je výrazně rozšířen.

Obě výlevky jsou vyrobeny $\mathrm{z}$ jemného keramického těsta s drobnými šupinkami slídy. Střep je vypálen do cihlové barvy, místy barva střepu přechází do světle šedé barvy. Oba zlomky jsou pokryty tmavě olivově zelenou (tmavě hnědou) glazurou.

Datace: nelze datovat (nestratifikované nálezy, většina jich náleží 2. polovině 13. - 14. století) Lit.: Sedláčková-Zi̊bek 2005

Uloženo: dočasně depozitář Archaia Brno

Pozn. nepodařilo se dohledat

Obr. 5:9

\section{5) Dominikánská 7}

k. ú. Město Brno, parc. č. 475/3, výzkum Archaia Brno (A00/10), inv. č. 206174/1299, odpadní jímka s.j. 554 
Spodní část nádoby s náběhem na dva vylévací otvory umístěné v protilehlé poloze. Keramické těsto vypálené do cihlové barvy, místy do světle šedých odstínů. Povrch nádoby je pokryt olivově zelenou glazurou, na vnitřku nádoby jsou patrné kapky glazury.

Dochovaná výška: $85 \mathrm{~mm}$

Průměr dna: $115 \mathrm{~mm}$

Datace: 1. polovina 14. století

Lit.: Merta-Zapletalová-Zůbek 2001

Uloženo: Muzeum města Brna

Obr. 5:4 a 6:3

\section{6) Veselá ulice - Janáčkovo kulturní centrum}

k. ú. Město Brno, parc. č. 593, výzkum Archaia Brno (A006/2015), inv. č. 1332/94, odpadní vrstva s. j. 1332

Výlevka třmenové konvice v podobě hlavičky beránka. Přibližně uprostřed délky výlevky jsou namodelovány masivní rohy, zatočené téměř až na spodek výlevky. U kořenů rohů jsou kroužkem naznačena očka, panenka je zvýrazněna vtlačeným trojúhelníčkem. Tlamička v podobě výlevky se mírně rozšiřuje.

Střep je vypálen do světle šedé až cihlové barvy. Vnější povrch je pokryt tmavě (olivově) zelenou glazurou, jejíž kapky nacházíme i uvnitř. Pouze spodek výlevky není glazurou opatřen.

Vnitřní průměr vylévacího otvoru: $7 \mathrm{~mm}$

Datace: 14. století

Lit.: Staněk-Zůbek 2015-2016

Uloženo: dočasně depozitář Archaia Brno

Obr. 5:6 a 6:2

\begin{tabular}{|l|l|}
\hline Označení vzorku & Veselá ulice - Janáčkovo kulturní centrum (A006/2015), inv. č. 1332/94 \\
\hline Charakteristika střepu & keramika ze sprašové hlíny s glazovaným povrchem \\
\hline Zrnitost & velmi jemná \\
\hline Porozita & $8 \%$ úzké protáhlé póry \\
\hline Pojivo & homogenní \\
\hline Mikrostruktura & všesměrně velmi jemně zrnitá \\
\hline Hlavní složky & $\begin{array}{l}\text { ostřivo } 43 \% \\
\text { pojivo } 52 \% \\
\text { porozita } 5 \%\end{array}$ \\
\hline Modální složení & $\begin{array}{l}\text { Úlomky minerálů: křemen, biotit, muskovit, akcesoricky plagioklasy, alkalické živce. } \\
\text { Úlomky hornin: křemence, metakvarcity, kataklazity. }\end{array}$ \\
\hline Mikropetrografický & $\begin{array}{l}\text { Křemen tvoří nepravidelně omezená až stř́ipkovitá zrnka. } \\
\text { Živce se vyskytují sporadicky. Obvykle jsou ostrohranné až poloostrohranné s názna- } \\
\text { ky tabulkovitých průřezů. Jsou čiré i přeměněné. V produktech přeměn se vyskytují } \\
\text { jílové minerály a sericit. } \\
\text { Bezbarvý muskovit spolu s rezavě hnědým biotitem jsou součástí pojiva, velmi vzácně } \\
\text { se vyskytují jejich větší tabulky v ostřivu. Muskovit bývá podstatnou součástí horni- } \\
\text { nových úlomků - sericitových břidlic. } \\
\text { Zúlomků hornin byly identifikovány křemence, metakvarcity, kataklazity a slídové } \\
\text { (sericitové) břidlice. Křemence jsou tvořeny izometrickými nerovnoměrně zrnitými } \\
\text { křemeny, místy obsahují Fe-oxyhydroxidy. } \\
\text { Metakvarcity jsou složeny z drobných protáhlých útvarů křemene, které jsou místy } \\
\text { prostoupeny sericitem. Vzácně se vyskytují klasty kataklazitů. }\end{array}$ \\
\hline
\end{tabular}


Výchozí surovina odpovídá složením vzorku z Květinářské ulice (kat. č. 3, inv. č. 204/48). V analyzovaném výbrusovém preparátu nebyly zastiženy Fe-bročky, úlomky starší keramiky a úlomky sericitových břidlic. Teplota výpalu pravděpodobně

\section{7) Mlýnská ul. - Metropol}

k. ú. Trnitá, parc. č. 1148, výzkum Moravského zemského muzea v roce 1997, bez inv. č.

Výlevka v podobě hlavičky beránka, která je odlomena v místech napojení na tělo konvice. Přibližně uprostřed délky výlevky jsou namodelovány rohy, které jsou zatočeny až na spodek výlevky. Oči jsou naznačeny vtlačeným kroužkem a panenka zvýrazněna drobným důlkem. Ústí výlevky se mírně rozšiřuje.

Střep je vypálen do cihlové barvy a pokryt transparentní, oranžovou až olivově zelenou glazurou. Keramické těsto jemné s drobnými šupinkami slídy.

Vnitřní průměr vylévacího otvoru: $8 \mathrm{~mm}$

Datace: -

Lit.: -

Uloženo: Moravské zemské muzeum

Obr. 5:7 a 6:5

\section{8) Komárov - benediktinský klášter}

k. ú. Komárov, parc. č. 10, výzkum Muzea města Brna v roce 1976, inv. č. 321458

Výlevka v podobě hlavy blíže neurčeného zvířete (zajíce, lišky, psa?), jejíž pravá část je asi $\mathrm{z}$ jedné tř̌etiny odlomena. Přibližně uprostřed výlevky je namodelováno $35 \mathrm{~mm}$ dlouhé zašpičatělé ucho, které je zvýrazněno jemným prožlábnutím. Obdobně bylo asi původně utvářeno i pravé ucho, které se i s částí oka nedochovalo. V místě připojení levého ucha je plasticky ztvárněno oko - panenka je zvýrazněna důlkem a olemována koncentrickým kroužkem.

Střep je vypálen do cihlové barvy se světle šedým jádrem. Povrch je nerovnoměrně pokryt tenkou vrstvou olivově zelené glazury.

Vnitřní průměr vylévacího otvoru: $7 \mathrm{~mm}$

Datace: -

Lit.: Veselá 2003, kat. č. 9

Uloženo: Muzeum města Brna

Obr. 5:8 a 6:7

\section{9) Veselá ulice - Janáčkovo kulturní centrum}

k. ú. Město Brno, parc. č. 593, výzkum Archaia Brno (A006/2015), inv. č. 12119/14-15, odpadní vrstva s.j. 12119

Dva zlomky držadla a dva další střepy pokryté glazurou, které mohou pocházet z třmenové konvice, nebo aquamanile. U jednoho střepu je patrný náběh na výlevku (?). Průřez ucha je oválný. 
Keramické těsto je vypáleno do cihlové barvy se světle šedým jádrem. V těstě jsou patrné drobné šupinky slídy. Glazura je tmavě zelená, v místech tenčí vrstvy má glazura spíše hnědou barvu. Poleva absentuje na spodní části úchytky a vlastně ani samotná úchytka není glazurou pokryta souvisle. Drobné kapičky glazury pozorujeme i na vnitřní straně stř̌epů.

Datace: 2. polovina 13. - 14. století

Lit.: Staněk-Zůbek 2015-2016

Uloženo: dočasně depozitář Archaia Brno

Obr. 5:10

\section{0) Mečová 4}

k. ú. Město Brno, parc. č. 451, výzkum Archaia Brno (A00/10), inv. č. 202829/1169, suterén s. j. 596

Zlomek pravděpodobně třmenového ucha oválného průřezu. Ucho je odlomeno v místě napojení na okraj konvice.

Keramické těsto je vypáleno do cihlové barvy, na lomu je patrné světle šedé jádro střepu. Povrch je pokryt tmavě olivově zelenou glazurou.

Datace: 1. polovina 14. století

Lit.: Merta-Zapletalová-Zůbek 2001

Uloženo: Muzeum města Brna

Obr. 5:11 a 6:8

\section{1) Panenská ul.}

k. ú. Město Brno, parc. č. 619/1, výzkum Archaia Brno (A014/2009), inv. č. 459642, odpadní jímka s. j. 688 (výpľn s. j. 1267)

Horní část třmmenové konvice s jednou výlevkou. Třmenové ucho oválného průřezu vychází z válcovitého ústí o průměru $40 \mathrm{~mm}$, které je zdobeno nevýraznými žlábky. Ucho je dekorováno neuspořádanými šikmými vrypy. Dochovala se jedna výlevka stylizovaná do hlavičky blíže neurčeného zvířete s dlouhýma ušima. Uprostřed výlevky je do špičky namodelován výčnělek zdobený drobnými zářezy. Směrem $\mathrm{k}$ tělu konvice $\mathrm{z}$ něho vychází dva plastické pásky představující dlouhé uši, které jsou zdobeny rýhou. Oči chybí. Druhá výlevka není dochována, ale část namodelovaného pásku představující zbytek levého ucha prozrazuje, že i v tomto místě se původně výlevka nacházela.

Keramické těsto středně hrubé s četnými kamínky, na lomu růžové barvy, povrch světle šedý.

Dochovaná výška nádoby: $160 \mathrm{~mm}$

Průměr okraje: $60 \mathrm{~mm}$

Vnitřní průměr vylévacího otvoru: $13 \mathrm{~mm}$

Datace: 2. polovina 15. - 1. polovina 16. století (Pozn.: Jímka narušila dvě starší jímky s. j. 689 a 690 , které jsou předběžně datovány do 14. až 1. poloviny 15. století; zásyp jímky s. j. 688 proto 
obsahoval velké množství staršího materiálu, ke kterému snad můžeme počítat i studovanou konvici.)

Lit.: Holub-Staněk 2009-2014

Uloženo: Muzeum města Brna

Obr. 5:3 a 6:9

\section{2) Česká 5}

k. ú. Město Brno, parc. č. 558, výzkum AÚ ČSAV 1985, odpadni jímka s. j. 504

Dle ústního sdělení R. Procházky byla ze zásypu jímky vyzvednuta téměř celá třmenová konvice s výlevkami v podobě beraních hlaviček. Konvičku se nepodařilo dohledat.

Datace: $13 . / 14$. století

Pozn. Nálezy z jímky měly stejný charakter jako nálezy z jímky s. j. 505, ze které pochází mince Václava II. (1300-1305).

\section{Literatura}

AUCH, M.-TRZECIECZKI, M., 2007: Średniowiecze importy ceramiczne z badań na dziedzińcu głównym Pałacu Pod Blachą, Kronika Zamkowa 1-2, 127-154.

BELCREDI, L., 2006: Bystřec. O založení, životě a zániku středověké vsi. Archeologický výzkum zaniklé středověké vsi na Drahanské vrchovině 1975-2005. Brno.

BEUTMANN, J.-KENZLER, H., 2004: Weisse Miniaturgefässe des 12. bis 14. Jahrhunderts aus Sachsen in ihrem überregionalen Kontext, Arbeits- und Forschungsberichte zur sächsischen Bodendenkmalpflege 46, 485-494.

BLEKTA, J., 1934: Smilovo hradisko a Starý Plumlov, Ročenka Národopisného a průmyslového musea města Prostějova na Hané XI, 9-31.

CECH, B., 1984: Die Funde aus der spätmittelalterlichen Abfallgrube in Krems, Wegscheid 5, Archaeologia Austriaca 68, 279-311.

- 1987: Die mittelalterliche Keramik aus dem Kamptal und dem Horner Becken, Archaeologia Austriaca $71,173-302$.

ČAPEK, L.-MILITKÝ, J. a kol., 2016: Historická radnice v Českých Budějovicích ve světle archeologických výzkumů a rozboru hmotný pramenů. Plzeň - České Budějovice.

DEJMAL, M.-ZBRANEK, H., 2013: Zámecká jízdárna v Lednici - multifunkční centrum. Rkp. nálezové zprávy č. j. 22/2013, ulož. v archivu Archaia Brno.

ENDRES, W., 1998: Spätmittelalterliches Tischgeschirr in Regensburg. Regensburg im Mittelalter. Beiträge zur Stadtgeschichte vom frühen Mittelalter bis zum Beginn der Neuzeit. Regensburg.

FANSA, M., 1988: Zur Siedlungsgeschichte im Stadtkern von Oldenburg, Archäologische Mitteilungen aus Nordwestdeutschland, Beiheft 3, 42-53.

FELGENHAUER-SCHMIEDT, S., 1982: Katalog der mittelalterlichen Keramik. In: Keramische Bodenfude aus Wien, Mittelalter - Neuzeit (Harl, O., Hrsg.), 31-126. Wien.

FROLÍK, J. a kol., 1999: Frolík, J.-Hazlbauer, Z.-Charvát, P.-Šumberová, R.-Tomášek, M., Čáslav. Místo pro život. Čáslav.

GABRIEL, F.-SMETANA, J., 1983: K vývoji výrobních okruhů červeně malované keramiky v severních Čechách - Zur Entwicklung der Produktionsbereiche rotbemalter Keramik in Nordböhmen, AH 8, 119-138.

GREGEROVÁ, M. a kol., 2010: Gregerová, M.-Čopjaková, R.-Beránková, V.-Bibr, P.-Goš, V.-Hanuláková, D.-Hložek, M.-Holubová-Závodná, B.-Kristová, L.-Kuljovská, Z.-Macháček, J.-Ma- 
zuch, M.-Procházka, R.-Škoda, R.-V̌̌ianský, D., Petroarcheologie keramiky v historické minulosti Moravy a Slezska. Brno.

GROSS, U., 1991: Die Bügelkanne, eine Hauptform der süddeutschen Keramik des Hoch- und Spätmittelalters, Beiträge zur Mittelalterarchäologie in Österreich 7, 69-77.

- 1991a: Mittelalterliche Keramik zwischen Neckarmündung und Schwäbischer Alb. Bemerkungen zur räumlichen Entwicklung und zeitlichen Gliederung. Forschungen und Berichte der Archäologie des Mittelalters in Baden-Württenberg. Band 12. Stuttgart.

GROSSMANNOVÁ, D.-NAVRÁTIL, A., 2016: Depot moravských středních brakteátů z obce Prštice Depot mährischer mittlerer Brakteaten aus der Gemeinde Prštice, Folia numismatica 30, 105-118.

HAVRDA, J.-MATĚJKOVÁ, K., 2014: Hrnčíŕi ve středověké Praze. Výsledky výzkumu výrobních zařízení z Malé Strany v kontextu dosavadních poznatků - Töpfer im mittelalterlichen Prag: Ergebnisse einer Untersuchung von Produktionsanlagen von der Prager Kleinseite im Kontext der bisherigen Erkenntnisse, AH 39, 23-51.

HEINZ-MOHR, G., 1999: Lexikon symbolů. Obrazy a znaky křest’anského umění. Praha.

HENTSCH, L., 2010: Hrnčířská produkce Malé Strany ve vrcholném stř̌edověku. Rkp. diplomové práce, ulož. na FF ZČU v Plzni.

HLOŽEK, M.-JORDÁNKOVÁ, H.-LOSKOTOVÁ, I., 2018: The provenance of raw materials for the manufacture of a knight stove from Petrov - Provenience surovin k výrobě rytířských kamen $\mathrm{z}$ brněnského Petrova, AH 43, 491-509.

HOFFMANN, Y., 1997: Rotbemalte Irdenware des Mittelalters und der frühen Neuzeit in Sachsen. Forschungen zu Archäologie und Baugeschichte 11, 31-65.

HOLL, I., 1963: Középkori cserépedények a budai várpalotából Mittelalterliche - Keramik aus dem Burgpalast von Buda, 13.-15. Jahrhundert, Budapest Régiségei 20, 335-394.

- 1973: Sopron Közepkori Városfalai IV, Archeológiai Értesítö 100, 180-208.

- 2005: Der gedeckte Tisch vom 13. bis 15. Jahrhundert in Buda im Lichte der archäologischen Funde. Tischgerät im spätmittelalterlichen Buda. Archäologische Angaben und deren Schranken, Acta Archaeologica Academie Scientiarum Hungarie 56, 321-384.

HOLUB, P.-STANĚK, P., 2009-2014: Terénní dokumentace z výzkumu A014/2009 Brno, PD Panenská, ulož. v archivu Archaia Brno.

HOŠŠO, J., 1983: Prehlad vývoja stredovekej keramiky na Slovensku - Entwicklungsübersicht der mittelalterlichen Keramik in der Slowakei, AH 8, 215-231.

- 1997: Príspevok k štúdiu materiálnej kultury na území Bratislavy v období v období stredoveku a na začiatku novoveku - Beitrag zum Studium der Sachkultur auf dem Gebiet der Stadt Bratislava im Mittelalter und am Anfang der Neuzeit, AH 22, 287-300.

- 1997a: Odpadová jáma patricijského domu v Bratislave. Príspevok k výbave domácnosti v neskorom stredoveku. In: Z pravěku do středověku. Sborník k 70. narozeninám Vladimíra Nekudy (Nekuda, R.-Unger, J., edd.), 175-183. Brno.

HOŠŠO, J.-LESÁK, B., 2001: Archeologický výskum horizontu 12. až 13. storočia v historickom jadre Bratislavy (Príspevok k morfologickým a technologickým zmenám v keramike a k počiatkom mestotvorného procesu) - Archäologische Erforschung des 12.-13. Jahrhundertshorizonts im Stadtkern Bratislava (Beitrag zu den morphologischen und technologischen Veränderungen in der Keramikproduktion und zum Anfang der Stadtbildung), AH 26, 241-256.

HRUBÝ, P. a kol., 2006: Hrubý, P.-Jaroš, Z.-Kočár, P.-Malý, K.-Mihályiová, J.-Militký, J.-Zimola, D., Stř̌edověká hornická aglomerace na Starých Horách u Jihlavy - Das mittelalterliche Bergbauzentrum in Staré Hory (Altenberg) bei Jihlava (Iglau), PA XCVII, 171-264.

HUBER, E. H., 1992: Ein Töpferofen in Wien 1, Griechengasse/Hafnersteig, Beiträge zur Mittelalterarchäologie in Österreich 8, 85-95.

- 2011: Spielen und Form. Bügelkannen mit zoomorphen Ausgussröhren aus dem keramischen Fundgut Wiens, Beiträge zur Mittelalterarchäologie in Österreich 27, 91-101.

HUBER, E. H.-KÜHTREIBER, K.-SCHARRER, G., 2003: Die Keramikformen des Hoch- und Spätmittelalters im Gebiet der heutigen Stadt Wien sowie der Bundesländer Niederösterreich und Burgenland. In: Beiträge vom 34. internationalen Hafnerei Symposium auf Schloss Maretsch in Bozen/ Südtirol 2001 (Spindler, K.-Stadler, H., Hrsg.), 43-66. Innsbruck.

JANSSEN, H., 1983: Later medieval pottery production in the Netherlands. In: Ceramics and Trade (Davey, P.-Hodges, P., edd.), 121-185. Scheffield. 
KALTENBERGER, A., 2009: Keramik des Mittelalters und der Neuzeit in Oberösterreich. Band 1. Grundlagen. Studien zur Kulturgeschichte von Oberösterreich 23. Linz.

- 2009a: Keramik des Mittelalters und der Neuzeit in Oberösterreich. Band 2. Katalog, Studien zur Kulturgeschichte von Oberösterreich 24. Linz.

KELLER, Ch., 1999: Gefässkeramik aus Basel. Text, Materialhefte zur Archäologie in Basel. Heft 15a. Basel.

- 1999a: Gefässkeramik aus Basel. Katalog. Materialhefte zur Archäologie in Basel. Heft 15b. Basel.

KENZLER, H., 2001: Archäologische Untersuchungen zum Kornmarkt in Zwickau. Keramikchronologie - Platzgeschichte - Stadtgeschichte. Dresden.

KLÁPŠTĚ, J., 1998: Die Anfänge der jüngeren mittelalterlichen Keramik in Böhmen als kulturhistorisches Problem, AR L, 138-158.

KLUTTIG-ALTMANN, R., 2006: Von der Drehscheibe zum Scherbenhaufen. Leipziger Keramik des 14.-18. Jahrhunderts im Spannungsfeld von Herstellung, Gebrauch und Entsorgung. Dresden.

KOUŘIL, P.-WIHODA, M., 2003: Etnické trojmezí? Výpověd’ písemných a hmotných pramenů k etnické struktuře moravsko-slezského pomezí v epoše vrcholného středověku - Ethnische Dreischeide? Aussage schriftlicher und materieller Quellen zur ethnischen Struktur des mährisch-schlesischen Grenzgebiets im Hochmittelalter, AH 28, 69-111.

KOVÁČIK, P.-DUDKOVÁ, V.-LAFKOVÁ, H., 2016: Poznatky ke stavebnímu vývoji a k pohřbívání v kostele sv. Kř́žze v Javorníku-vsi na základě archeologického výzkumu - New knowledge about construction, historical development and burials in St. Cross church in Javornik based on archaeological research, PV 57, č. 2, 177-196.

KRABATH, S., 2012: Die Entwicklung der Keramik im Freistaat Sachsen von späten Mittelalter bis in das 19. Jahrhundert. Ein Überblick. In: Keramik in Mitteldeutschland - Stand der Forschung und Perspektiven. 41. Internationales Hafnereisymposium des Arbeitskreises für Keramikforschung in Dresden, Deutschland vom 21. September bis 27. September 2008 (Smolnik, R., ed.), 35-171. Dresden.

KRENN, M., 2011: Wüstungsforschung und Denkmalpflege in Niederösterreich. Fundberichte aus Österreich. Band 20, Materialhefte Reihe A. Wien.

DIE KUENRINGER: Die Kuenringer. Das Werden des Landes Niederösterreich (Wolfram, H.-Brunner, K.-Stangler, G., edd.). Wien 1981.

LOBBEDEY, U., 1968: Untersuchungen mittelalterlicher Keramik. Berlin.

LÜDTKE, H., 1985: Die mittelalterliche Keramik von Schleswig. Ausgrabung Schild 1971-1975. Neumünster.

MADSEN, P. K., 1991: Mittelalterliche bleiglasierte Miniaturgefässe aus Ribe. In: Töpfereiforschung archäologisch, ethnologisch, volkskundlich. Beiträge des internationalen Kolloquiums 1987 in Schleswig (Lüdtke, H.-Rüdiger, V., Hrsg.), 427-440. Bonn.

MARETHOVÁ, B.-TURAKIEWICZ, R.-ZEZULA, M., 2018: Katalog vybraných archeologických nálezů z Opavy a Ratiboře. In: S knížaty u stolu. Kuchyně a kultura stolování na středověkých vévodských dvorech v Opavě a Ratiboři (Korbelářová, I.-Zezula, M., edd.), 209-233. Ostrava - Ratiboř.

MERTA, D.-ZAPLETALOVÁ, D.-ZŮBEK, A., 2001: Obchodní galerie Velký Špalíček. Rkp. nálezové zprávy č. j. 18/01, ulož. v archivu Archaia Brno.

MĚCHUROVÁ, Z., 1997: Konůvky - zaniklá středověká ves ve Ždánickém lese. Studie Archeologického ústavu AV ČR XVII/1. Brno.

MĚ̌̌íNSKÝ, Z.-UNGER, J., 1987: Zaniklá ves Koválov u Žabčic (archeologické nálezy). Mikulov.

MÜLLER, U., 1996: Novationsphasen und Substitutionsprozesse. Regelhafte Vorgänge am Beispiel des Handwaschgeschirrs im Hanseraum aus archäologischer Sicht. In: Nahrung und Tischkultur im Hanseraum (Wiegelmann, G.-Mohrmann, R.-E., Hrsg.), 125-165. Münster.

- 2006: Zwischen Gebrauch and Bedeutung. Studien zur Funktion von Sachkultur am Beispiel mittelalterlichen Handwaschgeschirrs (5./6. bis 15./16. Jahrhundert). Bonn.

ORNA, J. a kol., 2011: Keramická produkce města Plzně v období 14. a 15. století. Plzeň.

PARÁDI, N., 1973: Az Esztergom - Széchenyi Téri Ásatás - Ausgrabungen in Esztergom, Széchenyi-Platz, Archaeologiai Értesitö 100, 232-249.

PFROMMER, J.-GUTSCHER, D., 1999: Laufen Rathausplatz. Eine hölzerne Häuserzeile in einer mittelalterlichen Kleinstadt: Hausbau, Sachkultur und Alltag. Bern. 
PROCHÁZKA, R., 1996: Brněnská stolní a kuchyňská keramika 2. poloviny 14. století - počátku 15. století - Die Brünner Tisch- und Küchenkeramik aus der 2. Hälfte des 14. - Anfang des 15. Jahrhunderts, Pravěk NŘ 1994, č. 4, 323-344.

PROCHÁZKA, R.-HLOŽEK, M., 2013: Opavský džbán v Brně? K otázce počátků vrcholně středověké glazované keramiky - Opavian jug in Brno? To the question of the beginnings of the Late Middle Ages glazed pottery, Časopis Slezského zemského muzea - vědy historické - série B 62, 231-244.

PROCHÁZKA, R.-KOVÁČIK, P.-ZŮBEK, A., 2002: Nové poznatky k vývoji opevnění olomouckého hradu v raném a vrcholném středověku - Neue Erkenntnisse zur Entwicklung der Befestigung der Olmützer Burg im Früh- und Hochmittelalter, AH 27, 197-213.

PROCHÁZKA, R.-PEŠKA, M., 2007: Základní rysy vývoje brněnské keramiky ve 12.-13./14. století Forschungstand und bisherige Methodik des Studiums der Erforschung der Keramikproduktion des 12. Jhs.-Anfang 14. Jhs. in Mähren, PV 48, 143-299.

PŘIBYLOVÁ, M., 2013: Předlokační osídlení jižní části historického jádra Brna a jeho přerod v městský organismus v archeologických pramenech získaných v rámci archeologického výzkumu parcely Orlí 19-21. Rkp. bakalářské diplomové práce, ulož. na FF MU, Brno.

RICHTER, M., 1961: Nejstarší středověká polévaná keramika v Čechách - Die älteste mittelalterliche glasierte Keramik in Böhmen, PA LII, 573-579.

- 1982: Hradišt'ko u Davle - městečko ostrovského kláštera. Praha.

RICHTER, M.-VOKOLEK, V., 1995: Hradec Králové. Slovanská hradiště a počátky středověkého města - Hradec Králové - ein slawischer Burgwall und Beginn einer mittelalterlichen Stadt. Hradec Králové - Praha.

ROYT, J.-ŠEDINOVÁ, H., 1998: Slovník symbolů. Kosmos, příroda a člověk v křest’anské ikonografii. Praha.

SCHARRER-LIŠKA, G., 2007: Die hochmittelalterliche Grafitkeramik in Mitteleuropa und ihr Beitrag zur Wirtschaftsgeschichte. Forschungsstand - Hypothesen - offene Fragen. Mainz.

SCHARRER-LIŠKA, G.-SCHERRER, P., 2010: Hafner, Händler, Franziskaner. Archäologische Untersuchungen zum Mittelalter in St. Pölten, Niederösterreich. Beiträge zur Mittelalterarchäologie in Österreich. Beiheft 8. Wien.

SEDLÁČKOVÁ, L., 2015: Středověká keramika. In: Veselí nad Moravou. Stř̌edověký hrad v říční nivě (Plaček, M.-Dejmal, M., edd.), 188-217. Brno.

SEDLÁČKOVÁ, L.-ZŮBEK, A., 2005: Nálezová zpráva o provedení archeologického výzkumu při výstavbě „PALACE CD“, parc. č. 272/19, 272/20 a č. 637/1, k. ú. Brno-město. Etapa: Přeložka kanalizace v ulici Koliště. Rkp. nálezové zprávy č. j. 10/05, ulož. v archivu Archaia Brno.

SLIVKA, M., 1991: Mittelalterliche figurale Keramik in der Slowakei - Stredoveká figurálna keramika na Slovensku, SlArch XXXIX, 331-364.

ŠIKULOVÁ, V., 1985: Středověká polévaná keramika z Opavy - Mittelalterliche glasierte Keramik aus Opava (Troppau), AH 10, 230-233.

STANĚK, P.-PEŠKA, M., 2014: Brno, Česká 6 rekonstrukce objektu. Rkp. nálezové zprávy, ulož. v archivu Archaia Brno.

STANĚK, P.-ZŮBEK, A., 2015-2016: Terénní dokumentace z výzkumu A006/2015 Brno, Janáčkovo kulturní centrum, ulož. v archivu Archaia Brno.

TURAKIEWICZ, R., 2010: Ratownicze badania na Starym Mieście w Raciborzu, województwo śląskie. In: Badania archeologiczne na Górnym Śląsku i ziemiach pogranicznych w latach 2007-2008 - Archeologické výzkumy v Horním Slezsku a na jeho pomezí v letech 2007-2008 (Tomczak, E., ed.), 142-156. Katowice.

UNGER, J., 1981: Hradištní a středověká osada u Šakvic, okr. Břeclav - The hillfort and medieval settlement Near Šakvice, Břeclav dist., AR XXXIII, 55-87.

- 1984: Základní horizonty keramiky 12.-15. stol. na soutoku Jihlavy a Svratky, okr. Břeclav - Basic pottery groups of the 12 th to 15 th centuries A. D. on the confluence of the Jihlava and Svratka rivers, district of Břeclav, AR XXXVI, 288-296.

- 1984a: Zaniklá ves Topolany u Vranovic (okr. Břeclav) - Die Ortswüstung Topolany bei Vranovice, Kr. Břeclav, AH 9, 65-100. 
VAŘEKA, P., 1998: Proměny keramické produkce vrcholného a pozdního středověku v Čechách The erratic character of ceramic production in the High and Later Middle Ages in Bohemia, AR L, $123-137$.

VESELÁ, P., 2003: Nálezy hliněných akvamanilií v Brně. Rkp. první seminární práce na ÚAM FF MU, Brno.

ZATLOUKAL, R., 1999: Zpráva o archeologickém výzkumu ve Žd'áře nad Sázavou, trat' Staré Město, v letech 1996-1999. In: Mediaevalia archaeologica 1 (Ježek, M.-Klápště, J., edd.), 193-207. Praha - Wrocław.

ZIMOLA, D., 2014: Osídlování centrální části Českomoravské vrchoviny ve vrcholném středověku. Rkp. disertační práce, ulož. na ÚAM FF MU, Brno.

\section{Internetové zdroje}

Antonius von Pforr, Buch der Beispiele, Univerzitní knihovna v Heidelbergu (Švábsko, kolem 14801490, Cod. Pal. germ. 85, fol. 128r, čerpáno z: https://digi.ub.uni-heidelberg.de/diglit/cpg85/0263/image, cit. 30. 9. 2018.

Keramická závěsná konvice z Dordrechtu (Holandsko; Museum Boijmans van Beuningen), čerpáno z: http://boijmans.intermax.devurl.nl/en/object/51680/hanging-cistern/Anonymous, cit. 30. 9. 2018.

Keramická závěsná konvice z Kolína nad Rýnem (Německo; Museum für Angewandte Kunst Köln, čerpáno z: https://www.kulturelles-erbe-koeln.de/documents/obj/05738392, cit. 30. 9. 2018.

Keramická závěsná konvice z Leidenu (Holandsko; Museum Boijmans van Beuningen), čerpáno z: http:// boijmans.intermax.devurl.nl/en/object/53239/hanging-cistern/Anonymous, cit. 30. 9. 2018.

Keramická závěsná konvice z Utrechtu (Holandsko; Museum Boijmans van Beuningen), čerpáno z: http://boijmans.intermax.devurl.nl/en/object/52510/hanging-cistern/Anonymous, cit. 30. 9. 2018.

Modlící se Panna Marie ve svém pokoji, Albertina muzeum ve Vídni, 1467, inv. č. DG1926/697, čerpáno z: http://sammlungenonline.albertina.at/?query=Inventarnummer=[DG1926/697]\&showtype $=$ record, cit. 30. 9. 2018.

Oltáŕ z Merode, dílna Roberta Campina, kolem 1427-1432, Holandsko, Metropolitní muzeum v New Yorku, inv. č. 56.70a-c; čerpáno z: https://www.metmuseum.org/art/collection/search/470304, cit. 30. 9. 2018.

Panna Marie v očekávání z Németújváru (dnešní Güssing, Rakousko), kolem 1410, Mad’arská národní galerie, inv. č. 52.656, čerpáno z: https://mng.hu/collection/maria-gravida-fragment-of-a-panel-from-nemetujvar-today-gussing-austria-34408, cit. 30. 9. 2018.

Výřez z Pašijového oltáře s motivem Krista před Pilátem, Mistr Bertram z Mindenu, kolem 1390, Dolnosaské státní muzeum v Hanoveru, čerpáno z: https:/cs.wikipedia.org/wiki/Mistr_Bertram\#/media/ File:Meister_Bertram_von_Minden_011.jpg, cit. 30.9. 2018.

\section{Zusammenfassung}

\section{Bügelkannen mit zoomorphen Ausgüssen in der Brünner Umgebung}

Bügelkannen sind in Brünn eine neue Keramikform, die sich gut mit der im 13. Jahrhundert aus den südlich und südwestlich von Mähren gelegenen Gegenden in Brünn ankommenden Bevölkerung in Verbindung bringen lassen. In der Brünner Umgebung begegnen wir Bügelkannen in drei verschiedenen Formen. Zu den ältesten zählen die „klassischen“ Bügelkannen (Abb. 1), die bereits vor Mitte des 13. Jahrhunderts in Brünn auftauchen (Horizont VS 1.2; ProcházkaPeška 2007, 223; Přibylová 2013, 68-71). Wohl bereits in der zweiten Hälfte des 13. Jahrhunderts, deutlicher jedoch in der ersten Hälfte des 14. Jahrhunderts, tauchen Bügelkannen in der Brünner Umgebung im Rahmen von Miniaturgefäßen auf, und zwar sowohl in glasierter, als auch in unglasierter Ausführung (Abb. 2 und 3). 
Wohl bereits am Ende des 13. Jahrhunderts tauchen Bügelkannen mit zwei Ausgüssen in Form von Tierköpfen auf, die - von einer Ausnahme abgesehen - immer mit einer Glasur versehen sind.

Unter den Brünner Funden wurden bislang zehn Exemplare dieses Typs Bügelkannen ausgemacht (Katalognr. 1-8, 11, 12). Weitere zwei Funde könnten vielleicht von diesem Typ abstammen (Katalognr. 9 und 10; Abb. 4-6). Bei ihnen handelt es sich um kleinere Exemplare mit einer Höhe von um die $15 \mathrm{~cm}$, mit dem Bügelhenkel erreichen sie dann eine Höhe von um die $20 \mathrm{~cm}$. Die Bügelhenkel mit ovalem bis rundem Querschnitt sind in der Regel deutlich bogenförmig gewölbt, immer in der Achse der Ausgüsse. Bis auf Ausnahmen fehlt bei den Kannen jegliche Verzierung. Die Keramikmasse wurde beim größten Teil der Funde in ziegelfarbigen Farbtönen gebrannt, manchmal wurde sie hellgrau gefärbt. Die Glasur ist in der Regel transparent orangefarben (Katalognr. 1, 5, 7, 8), es tauchen auch dunkelgrüne und braune Farbtöne (Katalognr. 4, 6, 9, 10), eine helle olivgrüne Glasur mit orangefarbenen Flecken (Katalognr. 3) und in einem Fall ein hellgelber Überzug (Katalognr. 2) auf. Das einzige Exemplar ohne Überzug ist die Kanne aus der Panenská-Str. (Katalognr. 11). Die Ausgüsse haben überwiegend die Form eines Widderkopfes.

Funde mit analogen Formen (Abb. 7) sind besonders aus Niederösterreich gut bekannt (Wien - Felgenhauer-Schmiedt 1982, 89-91; Huber 2011, 91-101; Perzendorf - Krenn 2011, 149, Taf. 106:240-15; Krems - Cech 1984, 283-284, Abb. 4; Eggenburg - Cech 1987, 193, Taf. 71:F1; Huber 2011, Abb. 20; Hausleiten - Die Kuenringer, 614, Kat. Nr. 833; St. Pölten - Scharrer-Liška-Scherrer 2010, 29, Abb. 11 und 12). Aufgeführt werden auch welche aus Bratislava (Hoššo 1997, 288; Hoššo-Lesák 2001, 249; Slivka 1991, 332, Kat. Nr. 4 und Abb. 4, Taf. IV:3) und einige interessante aus Ungarn stammende Exemplare (Abb. 7:11-13; Holl 2005, 321, Abb. 6; Parádi 1973, 237, Abb. 5). Datiert werden sie in die zweite Hälfte des 13. bis zur ersten Hälfte des 14. Jahrhunderts. Weitere Funde aus Tschechien sind uns - bis auf Ausnahmen (Koválov - Abb. 7:1; Měřínský-Unger 1987, 8-9, Abb. 36:9; Plzeň - Abb. 7:3; Orna a kol. 2011, 49-50) - nicht bekannt.

Für eine eindeutige zeitliche Einordnung der Bügelkannen mit zoomorphen Ausgüssen liefern die Brünner Funde keinen ausreichenden Rückhalt. Auch wenn eine nähere Datierung dieser Funde nicht möglich ist, so waren sie doch immer im Rahmen von Fundkomplexen des 14. Jahrhunderts präsent, deutlicher in dessen erster Hälfte.

Ähnlich wie in den Nachbargebieten können wir annehmen, dass diese Kannen Bestandteile des Tischgeschirrs der damaligen Haushalte waren. Sie konnten sowohl zum Ausgießen von Flüssigkeiten, als auch - in der Funktion eines Aquamanile - zum Händewaschen dienen. Auch kann die Möglichkeit nicht ganz ausgeschlossen werden, dass es sich um eine Kanne zur Aufbewahrung von Wasser für die persönliche Hygiene in bürgerlichen Schlafzimmern handeln könnte. Die zuletzt erwähnte Funktion erfüllten nämlich spätestens ab Anfang des 15. Jahrhunderts Lavabokessel aus Metall ähnlicher Formen, die wir von den Sammlungen vieler westeuropäischer Museen her kennen (vgl. etwa Müller 2006, 273) und deren funktionelle Verwendung im Bereich der persönlichen Hygiene auf zahlreichen ikonographischen Quellen abgebildet werden (Abb. 8).

Bei den „klassischen“ Bügelkannen zweifeln wir nicht an, dass sie von lokalen Töpfern hergestellt wurden. Bei den glasierten Bügelkännchen sind wir beim heutigen Erkenntnisstand nicht dazu in der Lage zu sagen, ob sie von lokalen Töpfern hergestellt worden sein konnten, oder ob es sich um Importware handelt. Die mikropetrographischen Analysen der Keramikmasse von drei Kannen mit zoomorphen Ausgüssen (Kat.-Nr. 1, 3 und 6) deuten darauf hin, dass zumindest ein Teil dieser in Brünn gefundenen Kannen von lokalen Töpfern, ggf. von Töpfern aus der nahen Umgebung hergestellt worden sein konnten. Diese Annahme wird auch durch die ein wenig unterschiedliche stilistische Auffassung der Brünner Kannen im Vergleich zu den niederösterreichischen Exemplaren gestützt. Man kann annehmen, dass gerade die niederösterreichischen Funde für die lokalen Erzeugnisse eine Inspirationsquelle darstellten. 
Der vorliegende Beitrag wurde gefördert von den Projekten: „Hochmittelalterliche Keramik als Bestandteil des mobilen kulturellen Erbes“ im Programm des Kulturministeriums zur Förderung der angewandten Forschung und experimentellen Entwicklung der nationalen kulturellen Identität (NAKI II), Ident.-Code des Projektes DG18P02OVV020 und „Quellen und Verbreitung ausgewählter Handelswaren der Keramikproduktion des Hoch- und Spätmittelalters“, Ident.-Code GA17-13967S.

Mgr. Lenka Sedláčková, Archaia Brno, z. ú., Bezručova 15/78, 60200 Brno, Česká republika, lsedlackova@archaiabrno.cz

Mgr. Pavel Staněk, Archaia Brno, z. ú., Bezručova 15/78, 60200 Brno, Česká republika, stanek@archaiabrno.cz

Mgr. Martin Hložek, Ph.D., Ústav archeologie a muzeologie Filozofické fakulty Masarykovy univerzity, Arna Nováka 1, 60200 Brno, Česká republika, 10001@mail.muni.cz 
